Article

\title{
Evaluation of Environmental and Economic Sustainability for the Building Envelope of Low-Carbon Schools
}

\author{
Frida Bazzocchi (1), Cecilia Ciacci and Vincenzo Di Naso *(1) \\ Department of Civil and Environmental Engineering, University of Florence, 50139 Florence, Italy; \\ frida.bazzocchi@unifi.it (F.B.); cecilia.ciacci@unifi.it (C.C.) \\ * Correspondence: vincenzo.dinaso@unifi.it
}

check for

updates

Citation: Bazzocchi, F.; Ciacci, C.; Di Naso, V. Evaluation of Environmental and Economic Sustainability for the Building Envelope of Low-Carbon Schools. Sustainability 2021, 13, 1702. https://doi.org/10.3390/su13041702

Academic Editor: Giuseppe Margani Received: 23 December 2020

Accepted: 2 February 2021

Published: 4 February 2021

Publisher's Note: MDPI stays neutral with regard to jurisdictional claims in published maps and institutional affiliations.

Copyright: (c) 2021 by the authors. Licensee MDPI, Basel, Switzerland. This article is an open access article distributed under the terms and conditions of the Creative Commons Attribution (CC BY) license (https:// creativecommons.org/licenses/by/ $4.0 /)$.

\begin{abstract}
To achieve a carbon-free economy by 2050, the construction of low-carbon schools in Italy must select the proper structural and technological solutions for the building envelope while ensuring a low economic cost. The aim of this study was to analyze and compare several technological solutions for the building envelope and the related structural solutions in terms of thermo-dynamic properties, energy performance, environmental sustainability parameters, and economic evaluations, to obtain one or more alternatives. After a general study, the binomial load-bearing structure-external wall was investigated given its strong influence on both the environment and the total cost. The solutions were used in a new typological model for the kindergarten. All the solutions are comparable from an energy and environmental point of view, obtaining a primary energy demand of $<25 \mathrm{kWh} /\left(\mathrm{m}^{2}\right.$ year) and an environmental impact of $<20 \mathrm{kWh} /\left(\mathrm{m}^{2}\right.$ year). However, considering the economic factor and analyzing the binomial load-bearing structure-external wall, the advisable solutions are those that use wooden structures with insulation layer in wood fiber as they have a significantly lower environmental impact, along with the same good energy performance and have an acceptable cost compared to other analyzed solutions.
\end{abstract}

Keywords: building envelope; sustainable schools; low carbon; nZEB; economic sustainability

\section{Introduction}

Given the several aspects of sustainability, including social, environmental, and economical, schools are buildings that play a triple role: Educational, social, and cultural. At the educational level, schools as institutions provide instruction on topics and extracurricular activities and teach students and their families to respect and protect the natural environment and save energy, from the earliest years of school. The environmental certifications specifically reference the teaching of subjects relevant to sustainability. For instance, the Leadership in Energy and Environmental Design (LEED) protocol under the Innovation in Design category refers to "the school as a teaching tool" and awards one point of the certification to schools introducing the theme of sustainability into the curriculum activities and workshops. Pietrapertosa et al. [1] described the results obtained through a learning by doing project (Schools4energy) conducted between 2018 and 2019, which involved students between 3 and 14 years old and aimed to create a competition between different schools to reduce energy consumption through the correct behavior of users (particularly students).

Socially, schools as institutions have become civic centers, acting as places of reference not only for teachers, students, and families, but for the whole local community. Hence, several functional units are used during extracurricular hours for various activities. They are a multicultural place, open to everyone, hosting children of all ethnic groups, including those from disadvantaged backgrounds, promoting social inclusion and fighting inequality. In addition, education has been a right for every child since 20 November 1959, with the Declaration on the Rights of Child proclaimed in New York by the United Nations, and later with the Convention of the Rights of Child in 1989. The first document states that primary education must be free and compulsory for every child, without distinction. 
Culturally, the school buildings provide an example of sustainable architecture, a real 3D textbook [2] from which both children, actively participating in the management of the building, and the neighborhood can learn about respect for the environment and the principles of sustainability and acquiring increased awareness. Tucker et al. [3] showed that students in a school built according to sustainability have a better attitude toward environmental protection and are more prone to saving energy. The sustainable school building can provide a starting point for the regeneration and redevelopment of entire neighborhoods, particularly in the suburbs. Both public and private institutions have a common interest in building environmentally friendly and low-carbon buildings for the European Union's goal of achieving a carbon-free economy by 2050.

The need for the construction of new school buildings or the redevelopment of existing schools with sustainable cost-effective measures is clear to satisfy the educational needs of compulsory schooling and ensure an adequate education for all children from widely different social backgrounds. The local administrations state that new constructions are required mainly for kindergarten and elementary school buildings. The need of schools for children 0-6 age in both Europe and Italy was outlined in Barcelona European Council in 2002 [4,5]. The Council established that the standards to meet are $33 \%$ for children 0-3 age and 99\% for those 3-6 age. According to a report by Istat (Istituto Nazionale di Statistica-National Statistical Institute) [6] in Italy the 33\% for children 0-3 age has not yet been reached. In fact, for the academic year 2018/2019 this percentage is equal to about $25 \%$.

Moreover, the Italian school heritage, which is mostly old and obsolete, is characterized by limited energy efficiency and low environmental performance. Of schools in Italy, 75\% were designed before 1976 [7]. In this year, the first law concerning the energy consumption of buildings at national level was enacted. In Italy in 2018, only $1 \%$ of school buildings were categorized as energy efficiency class A (global energy performance index for non-renewables $\mathrm{EP}_{\mathrm{gl}, \text { nren }}>0.8 \mathrm{EP}_{\text {gl,nren,rif,standard (2019/21) }}$ reference building global energy performance index for non-renewable) according to Legambiente's report on the quality of school buildings [7], while $45.3 \%$ were energy efficiency class $\mathrm{G}\left(\mathrm{EP}_{\mathrm{gl}, \mathrm{nren}}>\right.$ 3.50 $\mathrm{EP}_{\mathrm{gl}, \mathrm{nren}, \text { rif,standard (2019/21) }}$ [8]. In Italy, there are many financial plans for schools that could be used for the redevelopment of school buildings asset with respect to architecture, structure, and energy/environmental point of view. In 2012, the "Fondo unico edilizia scolastica" ("School Buildings fund") [9] by the Italian Government was established. It outlined that this fund must be dedicated to all resources and funds for schools. There are many initiatives in the past deal with schools, the main are the following ones: "Scuole sicure" ("Safe schools") [10] in 2013 that funded many improvement measures and the 60\% was concluded, "Scuole belle" ("Good-looking schools") [11] and "Scuole antisismiche" ("Anti-seismic schools") [12] in 2015, a three-year financial plan in 2019. The last financial plan for schools for 0-6 age is the fund "Asili nido e scuole dell'infaniza" ("Kindergartens and childhood schools") [9] settled in 2020 to improve existing buildings and to build new schools where needed in the range of time 2024-2034. In the past, one of the most important initiative for kindergartens is the fund "Poli per l'infanzia" ("Childhood care center") [13] dedicated precisely to the construction of new schools for children 0-6 age.

According to the Paris Agreement in 2015 concerning the reduction in greenhouse gas emissions into the atmosphere to $80 \%$ compared to the levels of the Kyoto Protocol, tackling climate change and, as required by the international standard 2030 Climate and Energy Package [14] and the Italian Ministerial Decree (DM) No. 162 of 26 June 2015 [8], dealing with the energy performance of buildings, new buildings must be constructed following the nearly zero-energy buildings (nZEB) standards and low-carbon construction. Consequently, to construct new carbon-zero school buildings in Italy, all possible energy and environmental strategies must be used that reduce the primary energy demand of the building and consequently its environmental impact.

In Italy, the current legislation deals with schools design and sizing dates to 1975 [15] and design manuals are completely outdated. Briefly, they are inappropriate because they 
propose typological models that do not comply with modern teaching methods needs. For the design of new school buildings, there are no specific reference or standards that simultaneously consider the new pedagogical methods that need new internal distribution with different types of areas or the current Italian and European legislation in terms of energy and emissions requirements.

The proper design of the building envelope can be considered a passive energy strategy that regulates the energy flow between the inside and outside [16,17]. Considering the huge surface area and weight and their composition with materials of different natures, the building envelope is the set of technical elements that most influences on the calculation of $\mathrm{CO}_{2}$ emissions for the construction of a building.

The main goal of this research was to propose several technological solutions both for the structure and external envelope for the construction of low-cost and environmentalfriendly kindergarten schools in Italy. Our aim is to encourage and ensure a sustainable school architecture for every child, with education their fundamental right, regardless of the social context. Therefore, in addition to proposing an accessible school that is better from a distributive and functional point of view [18], cost-effective technological and structural solutions are proposed; they reduce the environmental impact and safeguard the health of the children that grow up inside the schools.

The main objective of this work was achieved by analyzing different technological solutions for the building envelope combined with different solutions for a technologically compatible load-bearing structure (five different technological solutions for the external walls (EWs) and four for the roof) and comparing them with the current structural and technological solutions used for the construction of Italian school buildings (Tables 1 and 2, S1). For each EW component and its load-bearing structural solution, we compared the different technological solutions in terms of thermo-dynamic properties, environmental sustainability indexes, and economic evaluations. Applying the technological solutions to a typological model of a school building for kindergarten, which was previously outlined and taken as a reference, we compared the technological solutions in terms of annual energy demand for heating and cooling, internal surface temperature for the EW exposed to the south (related to inner thermo-hygrometric comfort), annual primary energy demand, and environmental impact $\left(\mathrm{CO}_{2}\right.$ emissions into the atmosphere in $\mathrm{kgCO}_{2} /\left(\mathrm{m}^{2}\right.$ year $)$ for the product stage, the end-of-life stage, the benefits and loads beyond the system boundary, and the servicing). The comparison between different types of building envelope was necessary because the choice of the most appropriate technological solution by the designer during the preliminary phase of the design process depends on the energy consumption of the building and its environmental impact, as well as on other issues such as cost, construction time, constructability, flexibility in deciding the arrangement and size of the openings in the façade, the availability of materials, and the construction traditions in the area. This study is part of a broader research work addressing the definition of a new building type for the construction of low-carbon kindergartens in Italy, outlined through the environmental and technological system and completed with the quantification of energy and environmental impacts [18].

The importance of this study and its practical implication is being first to address the designer during the early stage of the design process when choosing the most appropriate structural and technical solution to build a school to ensure an appropriate compromise between environmental, technological, and economical sustainability. Secondly, we suggest a method of evaluation that can be applied in different climate conditions by updating the climate characteristics and the legislation requirements for the considered site.

Most of the studies about school building envelopes in Italy have concerned the energy refurbishment of existing school buildings. Often, studies of existing schools have started with the monitoring of the buildings. Studies have many dealt with improving the energy performance of the building envelope (for instance, increasing the overall thermal transmittance or replacing windows) and understanding which are the most advisable improvements for existing school buildings to save energy and reduce the 
environmental impact at a reasonable cost [19-22]. For instance, de Santoli et al. [23] examined 1296 existing schools, classifying them in terms of general information, energy label, and building consumption, then analyzing the energy performance of the building envelope and the thermal system. They proposed some interventions to improve the envelope performance while complying with historical and architectural features and considering the costs of the different solutions. Ascione et al. [24] examined building envelopes, applying multi-objective optimization to improve the energy performance of an office building considering different climate zones in Italy. The optimization aimed at minimizing the energy consumption, the global cost, and the thermal discomfort.

Table 1. Technological solutions of the external walls (EWs). m, material; $t$, thickness (m); XLAM, cross-laminated timber; OSB, oriented strand board; $\mathrm{U}$, thermal transmittance $\left(\mathrm{W} / \mathrm{m}^{2} \mathrm{~K}\right)$

\begin{tabular}{|c|c|c|c|c|c|c|c|c|c|}
\hline \multirow{2}{*}{\multicolumn{2}{|c|}{$\begin{array}{l}\text { Solution } 1 \text { (S1) } \\
\text { tructure: Reinforced } \\
\text { Concrete Frame }\end{array}$}} & \multicolumn{2}{|c|}{ Solution 2 (S2) } & \multicolumn{2}{|c|}{ Solution 3 (S3) } & \multicolumn{2}{|c|}{ Solution 4 (S4) } & \multicolumn{2}{|c|}{ Solution 5 (S5) } \\
\hline & & \multicolumn{2}{|c|}{ Structure: Steel Frame } & \multicolumn{2}{|c|}{ Structure: Steel Frame } & \multicolumn{2}{|c|}{$\begin{array}{l}\text { Structure: Platform } \\
\text { Frame (Wooden) }\end{array}$} & \multicolumn{2}{|c|}{$\begin{array}{l}\text { Structure: XLAM } \\
\text { (Wooden) }\end{array}$} \\
\hline $\mathrm{m}$ & $t$ & $\mathrm{~m}$ & $t$ & $\mathrm{~m}$ & $t$ & $\mathrm{~m}$ & $t$ & $\mathrm{~m}$ & $\mathrm{t}$ \\
\hline $\begin{array}{l}\text { External } \\
\text { Plaster }\end{array}$ & 0.025 & $\begin{array}{l}\text { Cement } \\
\text { Board }\end{array}$ & 0.012 & $\begin{array}{l}\text { External } \\
\text { plaster }\end{array}$ & 0.025 & $\begin{array}{l}\text { External } \\
\text { Plaster }\end{array}$ & 0.025 & $\begin{array}{l}\text { External } \\
\text { Plaster }\end{array}$ & 0.025 \\
\hline Wood fiber & 0.08 & $\begin{array}{l}\text { Waterproof } \\
\text { and } \\
\text { windproof } \\
\text { sheet }\end{array}$ & 0.002 & $\begin{array}{l}\text { Autoclaved } \\
\text { aerated } \\
\text { concrete } \\
\text { blocks }\end{array}$ & 0.30 & Wood fiber & 0.02 & Wood fiber & 0.10 \\
\hline \multirow[t]{3}{*}{$\begin{array}{l}\text { Lightweight } \\
\text { bricks }\end{array}$} & 0.30 & Wood fiber & 0.14 & \multicolumn{2}{|l|}{ - } & OSB panel & 0.02 & XLAM & 0.13 \\
\hline & & $\begin{array}{l}\text { Plasterboard } \\
\text { panel }\end{array}$ & 0.015 & \multicolumn{2}{|c|}{ - } & Wood fiber & 0.12 & \multicolumn{2}{|c|}{-} \\
\hline & & \multicolumn{2}{|c|}{-} & \multicolumn{2}{|c|}{-} & $\begin{array}{l}\text { Waterproof } \\
\text { and } \\
\text { windproof } \\
\text { sheet }\end{array}$ & 0.002 & \multirow{2}{*}{\multicolumn{2}{|c|}{-}} \\
\hline & & \multicolumn{2}{|c|}{ - } & \multicolumn{2}{|c|}{-} & OSB panel & 0.02 & & \\
\hline $\begin{array}{c}\text { Mineral } \\
\text { wool }\end{array}$ & 0.04 & $\begin{array}{c}\text { Mineral } \\
\text { wool }\end{array}$ & 0.04 & $\begin{array}{c}\text { Mineral } \\
\text { wool }\end{array}$ & 0.04 & $\begin{array}{c}\text { Mineral } \\
\text { wool }\end{array}$ & 0.04 & $\begin{array}{c}\text { Mineral } \\
\text { wool }\end{array}$ & 0.04 \\
\hline $\begin{array}{l}\text { Plasterboard } \\
\text { panel }\end{array}$ & 0.015 & $\begin{array}{l}\text { Plasterboard } \\
\text { panel }\end{array}$ & 0.015 & $\begin{array}{l}\text { Plasterboard } \\
\text { panel }\end{array}$ & 0.015 & $\begin{array}{l}\text { Plasterboard } \\
\text { panel }\end{array}$ & 0.015 & $\begin{array}{l}\text { Plasterboard } \\
\text { panel }\end{array}$ & 0.015 \\
\hline $\begin{array}{l}\text { Plasterboard } \\
\text { panel }\end{array}$ & 0.015 & $\begin{array}{l}\text { Plasterboard } \\
\text { panel }\end{array}$ & 0.015 & $\begin{array}{l}\text { Plasterboard } \\
\text { panel }\end{array}$ & 0.015 & $\begin{array}{l}\text { Plasterboard } \\
\text { panel }\end{array}$ & 0.015 & $\begin{array}{l}\text { Plasterboard } \\
\text { panel }\end{array}$ & 0.015 \\
\hline $\mathbf{U}$ & 0.190 & $\mathrm{U}$ & 0.186 & $\mathrm{U}$ & 0.177 & $\mathrm{U}$ & 0.179 & $\mathbf{U}$ & 0.190 \\
\hline
\end{tabular}

Table 2. Technological solutions for the roof. $U$, thermal transmittance $\left(\mathrm{W} / \mathrm{m}^{2} \mathrm{~K}\right)$.

\begin{tabular}{|c|c|c|c|c|c|c|c|c|c|}
\hline \multicolumn{2}{|c|}{ S1 } & \multicolumn{2}{|c|}{ S2 } & \multicolumn{2}{|c|}{ S3 } & \multicolumn{2}{|c|}{ S4 } & \multicolumn{2}{|c|}{ S5 } \\
\hline $\mathrm{m}$ & $t$ & $\mathrm{~m}$ & $t$ & $\mathrm{~m}$ & $t$ & $\mathrm{~m}$ & $t$ & $\mathrm{~m}$ & $t$ \\
\hline Gravel & 0.05 & Gravel & 0.05 & Gravel & 0.05 & Gravel & 0.05 & Gravel & 0.05 \\
\hline $\begin{array}{c}\text { Bituminous } \\
\text { waterproofing } \\
\text { sheet }\end{array}$ & 0.005 & $\begin{array}{c}\text { Bituminous } \\
\text { waterproofing } \\
\text { sheet }\end{array}$ & 0.005 & $\begin{array}{c}\text { Bituminous } \\
\text { waterproofing } \\
\text { sheet }\end{array}$ & 0.005 & $\begin{array}{c}\text { Bituminous } \\
\text { waterproofing } \\
\text { sheet }\end{array}$ & 0.005 & $\begin{array}{l}\text { Bituminous } \\
\text { waterproofing } \\
\text { sheet }\end{array}$ & 0.005 \\
\hline Wood fiber & 0.22 & Wood fiber & 0.24 & Wood fiber & 0.24 & $\begin{array}{l}\text { Wood cement } \\
\text { panel }\end{array}$ & 0.022 & $\begin{array}{l}\text { Wood cement } \\
\text { panel }\end{array}$ & 0.022 \\
\hline Vapor barrier & 0.00045 & Vapor barrier & 0.00045 & Vapor barrier & 0.00045 & Wood fiber & 0.24 & Wood fiber & 0.18 \\
\hline Slope creed & 0.05 & Slope creed & 0.05 & Slope creed & 0.05 & Vapor barrier & 0.0004 & Wood fiber & 0.04 \\
\hline Brick slab & 0.32 & $\begin{array}{c}\text { Collaborating } \\
\text { slab }\end{array}$ & 0.045 & $\begin{array}{c}\text { Collaborating } \\
\text { slab }\end{array}$ & 0.045 & OSB panel & 0.02 & Vapor barrier & 0.00045 \\
\hline \multirow[t]{2}{*}{$\begin{array}{l}\text { Internal } \\
\text { plaster }\end{array}$} & 0.025 & $\begin{array}{l}\text { Corrugated } \\
\text { sheet slab }\end{array}$ & 0.0015 & $\begin{array}{l}\text { Corrugated } \\
\text { sheet slab }\end{array}$ & 0.0015 & - & & XLAM & 0.13 \\
\hline & & $\begin{array}{l}\text { Plasterboard } \\
\text { panel }\end{array}$ & 0.015 & $\begin{array}{l}\text { Plasterboard } \\
\text { panel }\end{array}$ & 0.015 & - & & - & \\
\hline $\mathbf{U}$ & 0.138 & $\mathrm{U}$ & 0.142 & $\mathbf{U}$ & 0.142 & $\mathbf{U}$ & 0.145 & $\mathbf{U}$ & 0.138 \\
\hline
\end{tabular}

In the paper, firstly the state of the art, mainly concerned with the current situation of school buildings asset in Italy and studies on external envelope, will be shown; secondly, the methodology used for the research will be outlined and the input data for the study will be detailed, then the main results of the performed analyses will be shown and discussed, and finally some conclusions for the study will be delineated. 


\section{State of the Art}

According to the Annual Report on Energy Efficiency 2020 by the National Agency for Energy Efficiency (ENEA), the primary energy demand in Italy in 2018 is about 57 Mtoe, of which only $19 \%$ is met through energy produced from renewables [25]. According to Eurostat statistics, a high percentage (43\%) of energy is consumed in Italy for civilian uses [25]. Considering the national school sector in 2012, the energy consumption was estimated to be about $1 \mathrm{Mtoe} /$ year, of which $77 \%$ was thermal energy requirements and the remaining $23 \%$ was electrical energy [26]. For instance, in accordance with a study performed during the European project COMMONCENSE in 2009, the thermal energy consumption for schools was estimated as $24-32 \mathrm{kWh} /\left(\mathrm{m}^{2}\right.$ year) for Rome and $73-85 \mathrm{kWh} /\left(\mathrm{m}^{2}\right.$ year) for Milan [27]. From the ENEA's analysis for 2009 concerning the thermal energy needs, the highest consumption was found for kindergartens (about $32 \%$ of school buildings in Italy), with an average ranging between 80 and $100 \mathrm{kWh} /\left(\mathrm{m}^{2}\right.$ year) [28]. Regarding the total energy consumption for the school sector in Italy, kindergartens require about $16 \%$ of the total. According to the Paris Agreement, for achieving a carbon-free economy by 2050, a reduction of $40 \%$ in greenhouse gas emissions into the atmosphere and the improvement in energy efficiency to a share of $32.5 \%$ in the construction of a new building are required; from the preliminary stage of the design process, all the energy and environmental strategies will be necessary to reduce the annual primary energy demand and its environmental impact.

In the three-year period before 2017, 500 new school buildings were built in Italy. By analyzing the available data regarding energy consumption (mainly related to climate zones $\mathrm{E}$ and $\mathrm{D})$, the energy requirement, on average, was about $26.6 \mathrm{kWh} /\left(\mathrm{m}^{2}\right.$ year), while the environmental impact for consumption during operational phase, on average, was about $13.2 \mathrm{kgCO}_{2} /\left(\mathrm{m}^{2}\right.$ year). However, for school buildings, most of the studies on their environmental impact in terms of $\mathrm{CO}_{2}$ emissions refer to existing buildings needing an energy upgrade. These studies mainly compared possible energy and environmental efficiency strategies to be adopted in schools to improve their energy performance and decrease their environmental impact [29-31].

The energy performance of a building, whatever its intended use, is related to three main topics: first, the physical behavior of the building, regulated precisely by the external envelope; secondly, the micro-climate of the different environments; and thirdly, by the internal hygro-thermal well-being required for the particular intended use [32]. The external envelope significantly influences the energy balance because it helps control the energy flow between the internal and external environments [33], essentially due to the difference in temperature that is created to ensure the thermo-hygrometric well-being of the occupants. The external envelope therefore affects the energy balance mainly in relation to its contribution to dispersion and the number of solar gains. Especially in a school building, when considering the different technological solutions to be adopted, natural materials should be used that respect the minimum environmental criteria (Criteri Ambientali Minimi (CAM)) [34] and that are not harmful to the health of children and teachers, who spend most of their time inside the school. CAM are a serious of requirements for 17 categories of product and services that must be satisfied when choose the best one in terms of life cycle assessment (LCA) among those available on market, with the aim of promoting environmentally friendly products and services in the context of obtaining a carbon-free economy by 2050. In the literature, the studies on the performance of the building envelope have compared several solutions with respect to thermal transmittance, the intrinsic properties of the different materials used, the material and thickness of the thermal insulation layer, and the surface mass [35]. These parameters influence the annual primary energy demand and the indoor comfort conditions, especially in terms of air temperature, during both winter and summer seasons. These studies mainly referred to residential buildings and existing buildings, including schools, which need upgrading from an energy point of view $[36,37]$. For instance, Alshamarani et al. [36], regarding the school building type, performed a LCA and calculated the energy consumed for heating and cooling by the possible technological 
solutions to be adopted for the EW of an existing building considering seven different EW solutions combined with four different load-bearing structures and three different insulation solutions (uninsulated case, minimum insulation, and recommended insulation). In a subsequent study, Alshamarani et al. [38] compared 14 different structural solutions combined with different types of envelope using an algorithm developed to assess cost (construction, operation, maintenance, and renovation) and environmental impact (LEED categories). They found that the optimal technological solution to build school buildings in USA and North America is based on precast concrete elements for both the structure and the EWs.

Concerning different types of buildings, other authors used a LCA to study the environmental impact of different types of insulation materials. For instance, Llantoy et al. [39] investigated three different types of insulation material (polyurethane, extruded polystyrene, and mineral wool) to assess the environmental impact and the reduction in energy demand for heating in the Mediterranean climate. According to their studies, the mineral wool has the lowest environmental impact (with an environmental payback period of seven years), providing the same thermal performance. In addition, considering the Mediterranean climate conditions, Stazi et al. [40] analyzed a super-insulated envelope in a residential building with wooden structure to propose some strategies to avoid the overheating problem in the warmest period identified through monitoring. They performed a parametric analysis of the external envelope considering different internal areal capacities but the same thermal transmittance. They considered the cost and the LCA of the different solutions. They concluded that the use of an inner massive layer (solid brick, $12 \mathrm{~cm}$ thick) for the external vertical wall can improve the internal comfort of the occupants. CarreteroAyuso et al. [41] analyzed different types of external envelopes used in the design of healthcare buildings in Spain to evaluate the issues related to the technological solutions and technical construction aspects that can lead to problems during the service life of the building. Ferrara et al. [42] analyzed and proposed different refurbishment strategies for the external envelope of a residential building to reduce the energy costs for heating and cooling. As design parameters to improve the external envelope performance, they considered: Thermal resistance of the insulation panel and solar absorption coefficient. Finally, Ascione at al. [43] compared different passive strategies related to the design of the external envelope for designing nZEB residential buildings in the Mediterranean area. They defined some guidelines to improve performance both in summer and winter.

Many authors considered the optimization of the insulation thickness of the external envelope considering three different aspects: environmental, energy and, economic [44]. The performance of the buildings was compared in terms of the energy demand for heating and cooling respectively $\left(\mathrm{kWh} /\left(\mathrm{m}^{2}\right.\right.$ year) and $\mathrm{MWh} /$ year $)$, net cost for energy for heating and cooling $\left(\$ / \mathrm{m}^{2}\right)$ [45-47], the global warming potential (GWP) for the evaluation of $\mathrm{CO}_{2}$ emissions into the atmosphere, the total cost including energy and environmental cost [48,49], and the payback period [50,51]. For instance, D'Agostino et al. [46], through a cost-optimal analysis for the optimization of the insulation layer in an office building, showed that excessive insulation in a Mediterranean climate does not always lead to an advantage in terms of energy savings, mainly due to the increased energy requirements for cooling during the summer season.

\section{Methods}

The 5 different solutions proposed in this paper were chosen in a previous phase of the research, starting with an analysis of the environmental and technological system of many school buildings built between 2003 and 2015 that received awards for their energy performance or their innovative internal distribution [52]. These solutions were the recurrent ones. Secondly, we analyzed the technological and structural solutions suitable for school buildings in Italy.

Five different technological solutions (Table 1) for the EW were analyzed in terms of thermal transmittance and thermodynamic properties (surface mass $\mathrm{M}_{\mathrm{s}}$, periodic thermal 
transmittance $\mathrm{Y}_{\mathrm{IE}}$, time shift $\varphi$, and attenuation $\mathrm{f}_{\mathrm{D}}$ ) to verify that they met the requirements of the current energy regulations [8]. The thermodynamic properties of the EWs were calculated according to Italian national Agency of Unification European Committee for Standardization International Organization for Standardization (UNI EN ISO) 13786: (i) The surface mass measured in $\mathrm{kg} / \mathrm{m}^{2}$ depends on the density of the materials composing the considered wall stratigraphy and their thickness, (ii) the periodic thermal transmittance allows evaluation of the capacity of the materials to attenuate and shift the thermal wave, (iii) the attenuation factor is the ratio between the periodic thermal transmittance and the thermal transmittance calculated in steady state, and (iv) the time shift indicating the time range in hours between the maximum peak outside air temperature and that inside, and depends on the density of the materials and their specific heat.

Then, the 5 different technological solutions for the EW and the roof stratigraphy were applied to the typological model, which has a compact shape and internal courtyard (model I1, Figure 1) [18]. A dynamic energy simulation with hourly time steps was performed using Energy Plus software [53], using Design Builder [54] as the graphical interface, to evaluate the energy performance of the building for each solution. The analysis was performed considering the energy requirements for heating and cooling and the annual primary energy demand as reference parameters due to the contribution of heating, cooling, artificial lighting, auxiliary energy, equipment, and domestic hot water (DHW). Since the electrical energy required for the needs of the building is provided on-site by photovoltaic panels on the roof, the conversion factor for the calculation of primary energy demand is equal to 1 [8]. At this stage, the hourly variation in the internal surface temperature of the technological solution for the EW of the south-facing classrooms on the designed day for the summer season ( $15 \mathrm{July}$ ) was also determined to enable comparison with the trend in the outdoor air temperature.

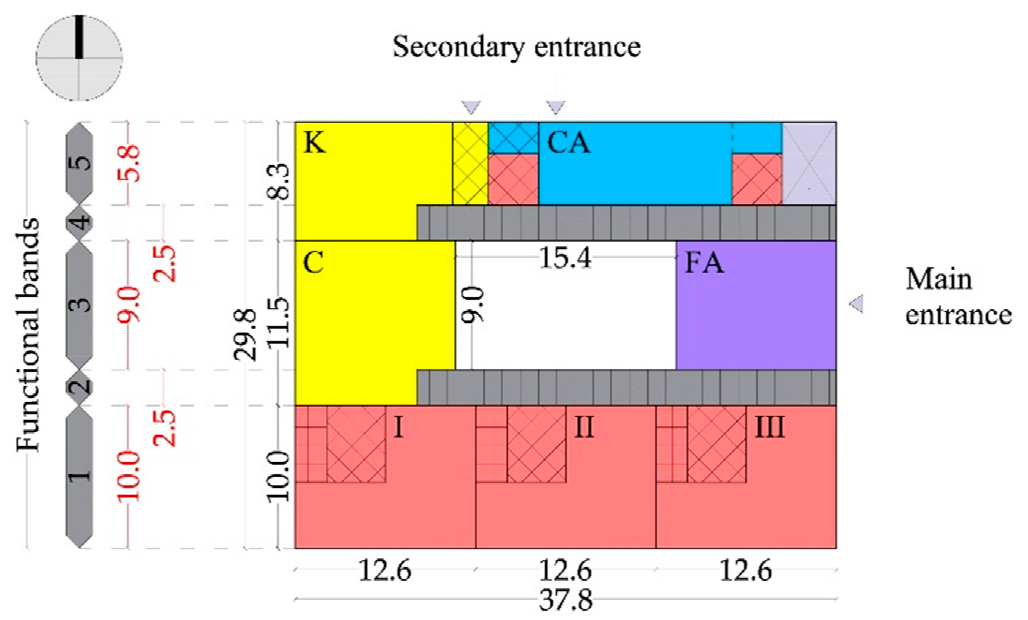

Home base - I/II/III 37.4\%

Free activities - FA $10.3 \%$

Canteen/Kitchen - C/K 16.7\%

Care area - CA $9.5 \%$

Horizontal connection $14.8 \%$

Figure 1. Typological model I1 for kindergarten. The 4 horizontal functional bands are showed on the left of the Figure 1 with grey bands and their sizes are in red.

The analysis was carried out considering Florence as a representative site in climate zone D [55]. However, the methodology used and the type of analysis could be extended to climatic zones that have the same climatic characteristics as zone D in terms, for instance, of heating and cooling degree days. The methodology proposed for this type of study could be used for other sites with different climate characteristics firstly by checking if the technological solutions proposed are proper for the considered climate, then updating the minimum requirements for the thermal properties of the technological solutions for the external envelope, according to the current legislation in chosen site, and finally updating the climate characteristics in the software used for the energy simulation in dynamic regime. 
Then, the $\mathrm{CO}_{2}$ emissions produced during both the construction and operational phases of the building were calculated according to the surface area of the building $\left(\mathrm{kgCO}_{2} /\left(\mathrm{m}^{2}\right.\right.$ year $\left.)\right)$. In this phase, the useful life of the building was considered as 50 years, with 30 years for the photovoltaic system that produces electricity on-site. The service life of some materials is must be considered lower than 50 years (lifespan of the building for LCA) because of their durability. For instance, for the bituminous waterproofing sheet and glazing panes for windows the service life was considered equal to 30 years. For those materials, the end-of-life (C3-C4) was considered.

The atmospheric emissions due to the construction phase of the building were calculated using eLCA software [56]. To calculate the environmental impact with eLCA, the product stage, the end-of-life stage, the benefits and loads beyond the system boundary, and the servicing were considered (construction phase). To calculate the environmental impact with eLCA, the product stage (A1-A3), the end-of-life stage (C3-C4), only for those materials with different service life with respect to the building lifespan (50 years), the benefits and loads beyond the system boundary (D1-D4), and the servicing were considered (construction phase). In this paper what happens at the end-of-life (C1-C4) and so after 50 years of lifespan of the school is not considered and calculated. This due to the lack of data about these stages in the available database for LCA [57]. Moreover, it is very difficult to know what happens after the service life of a building during the preliminary stage of the design process [58]. For instance, in Italy for a school building after 50 years of service life the designer could suppose the demolition and reconstruction of the building because the Italian Technical Standard for Construction required extraordinary maintenance of structure during the service life of the building (for lifespan higher than 50 years), but at the preliminary stage of the design process, the designer cannot know if this maintenance will be done or not. So, the choice of a probable demolition and reconstruction at the end-of-life could be the better choice in terms of safety. Moreover, some authors affirm that the $\mathrm{C} 1$ (demolition of end-of-life stage) has irrelevant environmental impact and C2-C4 is lower than $6 \%$ [59]. Finally, the environmental gain of the end-of-life stage can be considered only between $0.2-2.6 \%$ [60]. The conversion factor for the calculation of $\mathrm{CO}_{2}$ emissions due to the construction of the photovoltaic system was set to $50 \mathrm{gCO}_{2} / \mathrm{kWh}$ [61]. The conversion factor for emissions due to consumption for the operating phase (B) was assumed to be $0 \mathrm{kgCO} / 2 \mathrm{~m}^{2} \mathrm{kWh}$ because most of the electricity needs were produced on-site through renewables.

Once each stratigraphy for the building envelope and the related structural solution were established, we assessed the energy, environmental, and economic sustainability of the EW-structural solution binomial. This was necessary since this combination significantly influences both the environmental impact and the total cost of the construction [38]. For instance, regarding environmental impact, the GWP of the EW-load-bearing structure binomial (which is the sum of GWP for the EW and load-bearing structure) ranged between $20 \%$ (structural solution = wood) and $55 \%$ of the total. To estimate the environmental sustainability of the different solutions, 3 indices of the LCA were considered: (1) GWP in $\mathrm{kgCO}_{2} / \mathrm{m}^{2}$, (2) acidification potential (AP) in $\mathrm{kgSO}_{2} / \mathrm{m}^{2}$, and (3) total use of non-renewable primary energy resources (PENRT) in MJ. Some authors in the literature used these indices to evaluate the environmental impact of construction materials or buildings. For instance, Lizana et al. [29] considered for the energy rating the $\mathrm{CO}_{2}$ emissions in $\mathrm{kgCO}_{2} /\left(\mathrm{m}^{2}\right.$ year) and the Non-Renewable Primary energy consumption in $\mathrm{kWh} /\left(\mathrm{m}^{2}\right.$ year $)$. Estokova et al. [62] calculated the environmental assessment of 20 residential masonry houses considering the embodied energy (Potential environmental impact PEI in GJ), GWP in $\mathrm{tCO}_{2}$ eq, and $\mathrm{AP}$ in $\mathrm{tSO}_{2}$ eq. Moreover, Hollber et al. [63] outlined a wider review on visualizing method for LCA results and they include GWP and PENRT. Finally, Žegarac et al. [57] analyzed the LCA of cross-laminated timber buildings and they considered as indices GWP, AP, and PENRT.

We finished the study with cost analysis of the different alternatives proposed, since the construction of a new school and, in general, of a public building, is closely related 
to the financial means of the public administration that constructs the building. For a kindergarten, the economic incidence (which is the cost of the technological solution with respect to the total cost of the building) of the technological solution on the total cost of construction is about $8 \%$ [64]. The economic incidence of the structural solution (i.e., a wooden structure) is about 30\% [65]. The cost of each solution was based on the Regional Price List of Public Works of the Lombardy Region and other nationally trusted price lists (DEI price list).

Lastly, to enable comparison and establish the best EW-load-bearing structure combination in terms of sustainability for a kindergarten in Italy, a normalization was carried out comparing all solutions to the recurrent one used to build schools in Italy until today (Table 1, solution 1) considering GWP, primary energy demand, and cost.

The 3 indices considered for this evaluation will be combined in this way:

$$
n_{S_{i, i=2-5}}=\frac{G W P_{S i}}{G W P_{S 1}}+\frac{\operatorname{cost}_{S i}}{\operatorname{cost}_{S 1}}+\frac{\text { primary energy }_{S i}}{\text { primary energy } y_{S 1}},
$$

where the values of GWP and cost are calculated considering the sum of the single value for each element of both EW and structure for each technological solution. Specifically, the value of GWP is estimated by the sum of the impact of each element of the EW technological solutions and the structure solutions with respect to the GWP of the entire building. The value of the primary energy demand is calculated through energy simulation (Table A2). As shown by the equation the normalization was done with respect to solution 1 (Table 1, S1).

\subsection{Input Data}

As mentioned above, the study was conducting considering Florence as a representative city of the Mediterranean climate, characterized by 1415 heating degree days and belonging to climate zone $\mathrm{D}$.

For the analysis, the typological model for the kindergarten, characterized by a compact shape with internal courtyard and 3 classes (Figure 1), was considered. The building was developed on a single ground floor, without a prevailing geometric orientation and arranged according to 5 horizontal functional bands of different sizes. The functional band of the home base [66] is south-facing (functional band number 1 in Figure 1). Model I1 has an area of about $1050 \mathrm{~m}^{2}$, a volume of about $6000 \mathrm{~m}^{3}$, and is characterized by an aspect ratio (ratio surface to volume $(\mathrm{S} / \mathrm{V})=$ the surfaces through which the dispersions of the building occur $\left(\mathrm{m}^{2}\right)$ and the heated volume $\left.\mathrm{m}^{3}\right)$ [8] of $0.53 \mathrm{~m}^{-1}$.

The construction system considered as a reference for comparison with other possible technological solutions for building a low-carbon school is characterized by a reinforced concrete frame structure with an EW consisting of lightweight bricks $(0.30 \mathrm{~m})$, an external wood fiber insulation $0.08 \mathrm{~m}$ thick, an internal false-wall $0.10 \mathrm{~m}$ thick composed of a double plasterboard panel ( $0.07 \mathrm{~m}$ air cavity and two $0.015 \mathrm{~m}$ thick panel), and rock wool insulation $(0.04 \mathrm{~m})$ to ensure proper acoustic insulation of the façade (Table $1, \mathrm{~S} 1)$. The roof was built with a reinforced concrete slab $(0.32 \mathrm{~m})$, completed with a slope screed $(0.05 \mathrm{~m})$, a vapor barrier with polypropylene protection felt and polyethylene-copolymer film $(0.00045 \mathrm{~m})$, wood fiber insulation with a thickness of $0.24 \mathrm{~m}$, a bituminous waterproofing sheet with double reinforcement $(0.005 \mathrm{~m})$, and a gravel layer $(0.05 \mathrm{~m})$ (Table 2, S1). Wood fiber insulation was chosen for the stratigraphy of both the EW and the roof because it is commonly used for the construction of new school buildings in Italy. Wood fiber is a natural material with low $\mathrm{CO}_{2}$ emissions in the construction of the building. The technological solutions proposed as an alternative both related to the EW (Table 1, S2-S5) and to the roof (Table 2, S2-S5) are described in detail below (Figures 2 and 3). 
Solution 1

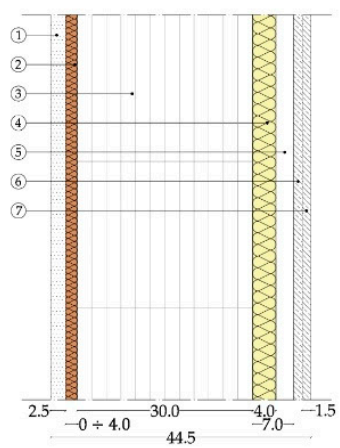

Solution 3

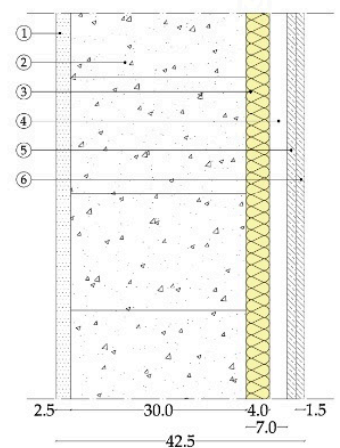

Solution 5

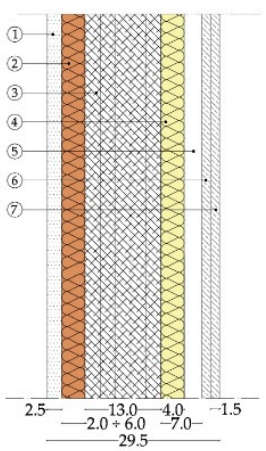

Solution 2

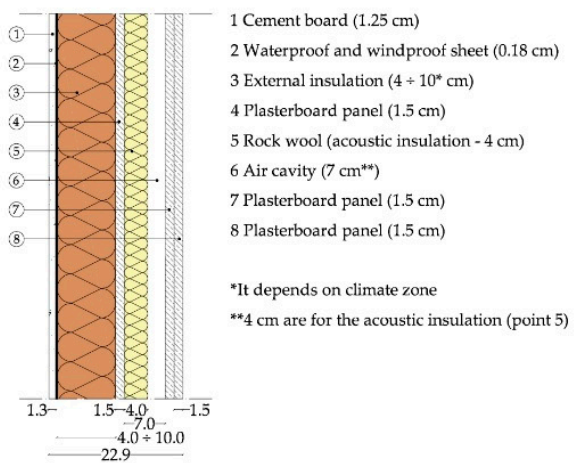

Solution 4

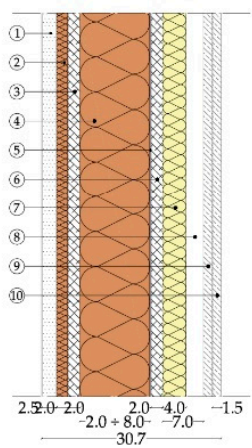

1 External plaster $(2.5 \mathrm{~cm})$

2 External insulation $(2 \mathrm{~cm})$

3 OSB panel $(2 \mathrm{~cm})$

4 Insulation layer $\left(2 \div 8^{*} \mathrm{~cm}\right)$

5 Waterproof and windproof sheet $(0.18 \mathrm{~cm})$

6 OSB panel $(2 \mathrm{~cm})$

7 Rock wool (acoustic insulation $-4 \mathrm{~cm}$ )

8 Air cavity $\left(7 \mathrm{~cm}^{* *}\right)$

9 Plasterboard panel $(1.5 \mathrm{~cm})$

10 Plasterboard panel $(1.5 \mathrm{~cm})$

"It depends on climate zone

${ }^{* * 4} 4 \mathrm{~cm}$ are for the acoustic insulation (point 7 )

Figure 2. Stratigraphy of the external walls for each analyzed solution.

- In solution 2, the building has a steel frame structure, an EW (dry solution) made of external cement board $(0.0125 \mathrm{~m})$, a waterproof and windproof sheet $(0.0018 \mathrm{~m})$ that is permeable to vapor, an insulation layer, a plasterboard panel $(0.015 \mathrm{~m})$, and an internal false wall, as in solution 1. The roof is composed of a corrugated steel sheet slab $(0.0015 \mathrm{~m}$ thick and $0.053 \mathrm{~m}$ high) with collaborating slab $(0.045 \mathrm{~m})$, slope screed (minimum $0.05 \mathrm{~m}$ ), a vapor barrier with polypropylene protection felt and polyethylenecopolymer film $(0.00045 \mathrm{~m})$, wood fiber insulation, bituminous waterproofing sheet with double reinforcement $(0.005 \mathrm{~m})$, and a gravel layer $(0.05 \mathrm{~m})$.

- For solution 3, the building has a steel frame structure, an EW with autoclaved aerated concrete blocks $(0.30 \mathrm{~m})$, and an internal false wall, as in solution 1 . The insulation layer is not present because the low thermal conductivity of the autoclaved aerated concrete blocks allows the required transmittance to be obtained without insulation. The technological solution is the same as that used for the roof in solution 2. 
- For solution 4 , the building has a wooden structure with a platform frame with $0.08 \times 0.16 \mathrm{~m}$ columns organized $0.60 \mathrm{~m}$ apart and $0.06 \times 0.12 \mathrm{~m}$ beams, an EW composed of a single oriented strand board (OSB, $0.02 \mathrm{~m}$ ), an insulation layer with a waterproof and windproof sheet $(0.0018 \mathrm{~m})$ that is permeable to vapor, a single OSB panel $(0.02 \mathrm{~m})$, and an internal false wall, as in solution 1 . The roof consists of a platform frame structure with a single OSB panel $(0.02 \mathrm{~m})$, a vapor barrier with polypropylene protection felt and polyethylene-copolymer film $(0.00045 \mathrm{~m})$, wood fiber insulation, a wood cement panel $(0.022 \mathrm{~m})$, a bituminous waterproofing sheet with double reinforcement $(0.005 \mathrm{~m})$, and a gravel layer $(0.05 \mathrm{~m})$.

- For solution 5, the building has a wooden structure with $0.13 \mathrm{~m}$ thick 5-layer crosslaminated timber (XLAM) panels, an EW with external insulation applied directly on the XLAM panel, and an internal false wall, as in solution 1. The roof has a wooden structure with a XLAM panel $(0.13 \mathrm{~m})$, a vapor barrier with polypropylene protection felt and polyethylene-copolymer film $(0.00045 \mathrm{~m})$, wood fiber insulation (low density, $0.04 \mathrm{~m}$ ), wood fiber insulation (high density), a wood cement panel $(0.022 \mathrm{~m})$, a bituminous waterproofing sheet with double reinforcement $(0.005 \mathrm{~m})$, and a gravel layer $(0.05 \mathrm{~m})$.

The technological solutions proposed for the stratigraphy of both external wall and roof are combined in such way because, at least in Italy, dry technological solutions for the external walls are usually combined with dry structural solutions for load bearing structure because of their construction approach based on prefabrication. The same thing happens for wet technological/structural solutions. These choices do not lead to any issues during the construction phase because the main possible criticalities have already been solved in the construction tradition.

Tables 1 and 2 shows the stratigraphy of the different technological solutions analyzed for the EW and roof (S1-S5), respectively, in terms of the material (m), thickness ( $\mathrm{t}$, in $\mathrm{m})$, and thermal transmittance $\left(\mathrm{U}\right.$, in $\left.\mathrm{W} / \mathrm{m}^{2} \mathrm{~K}\right)$ of the whole stratigraphy. The insulation thickness obtains half the thermal transmittance required by the current regulations for the reference building [8]. The thermal transmittance among the different technological solutions was kept similar facilitate comparison in terms of energy performance.

All the analyzed technological solutions ensure a value of $\mathrm{D}_{2 \mathrm{~m}, \mathrm{nT}, \mathrm{w}}$ (standardized façade sound insulation) higher than the requirement of the Italian standard [67] for schools. Moreover, the fire reaction is implicitly satisfied because of materials nature or treatment that are complying with the current Italian fire prevention regulation [68,69].

For the ground floor layers, the plastic formwork for the underfloor ventilation was used for all solutions, with a system screed $0.08 \mathrm{~m}$ thick, an expanded polystyrene (EPS) insulation layer $0.04 \mathrm{~m}$ thick completed with a radiant floor system of the same material $(0.05 \mathrm{~m})$, a lightweight screed $0.04 \mathrm{~m}$ thick for flooring, and an internal wooden floor $(0.015$ $\mathrm{m})$. Concerning windows, an aluminum thermal break frame was adopted (Thermal transmittance $\mathrm{U}_{\mathrm{f}}=1.7 \mathrm{~W} / \mathrm{m}^{2} \mathrm{~K}$ ) with double glazing, characterized by: (i) Thermal transmittance $\mathrm{U}_{\mathrm{g}}=1.2 \mathrm{~W} / \mathrm{m}^{2} \mathrm{~K}$, (ii) solar factor $\mathrm{g}=50 \%$, and (iii) solar transmittance $\mathrm{T}_{\mathrm{L}}=74 \%$.

The minimum value of the window-to-wall ratio (WWR) was defined according to the current health and hygiene regulations in Italy for the east, west, and north orientations, while it was assumed to be $50 \%$ for the south façade [70]. In the model, a fixed solar shading system with an overhang of $2.00 \mathrm{~m}$ and an automated internal solar shading (internal blinds) with control on the external temperature $\left(>24^{\circ} \mathrm{C}\right)$ for each south-facing functional unit [71] was used. For the energy simulation, the following design parameters for each single functional unit (thermal zone) were considered: (i) Occupancy (persons $/ \mathrm{m}^{2}$ ) according to Appendix A of UNI 10339 [72] (UNI Italian National Agency of Unification), (ii) minimum air flow rate according to the same legislation in Table III, (iii) heating setpoint of $20^{\circ} \mathrm{C}$ during activity periods and $10^{\circ} \mathrm{C}$ during the rest of the day in accordance with UNI/TS 11300-1, (iv) cooling setpoint temperature of $26^{\circ} \mathrm{C}$ during activity periods and $36{ }^{\circ} \mathrm{C}$ at other times in accordance with UNI/TS 11300-1, and (v) internal gains according to UNI/Technical Specification (TS) 11300-1 [73]. The system was considered with a heat 
pump for both heating (coefficient of performance $((\mathrm{COP})=3.6)$ and cooling (energy efficiency ratio $(E E R)=3.2$, and a mechanically controlled ventilation system with a heat recovery efficiency of $>65 \%$. On the roof, a photovoltaic system $\left(0.15 \mathrm{kWp} / \mathrm{m}^{2}\right)$ with east/west orientation and a tilt angle of $10^{\circ}$ was considered [74]. The photovoltaic system is on-grid, so electrical energy can be used from the public grid when the solar radiation is unavailable. However, electrical energy storage for the building is provided.

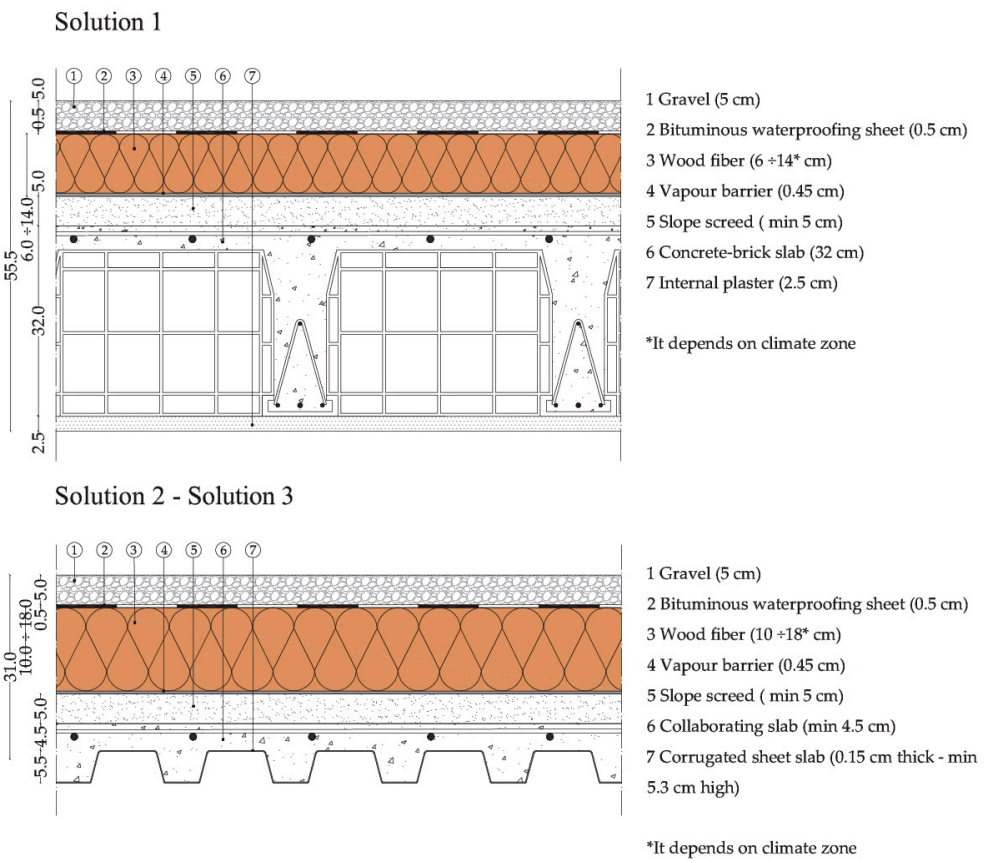

Solution 4

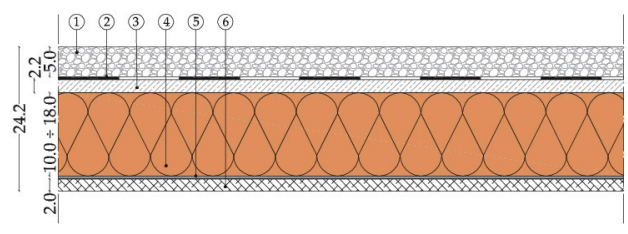

1 Gravel $(5 \mathrm{~cm})$

2 Bituminous waterproofing sheet $(0.5 \mathrm{~cm})$

3 Wood cement panel $(2.2 \mathrm{~cm})$

4 Wood fiber $\left(10 \div 18^{*} \mathrm{~cm}\right)$

5 Vapour barrier $(0.45 \mathrm{~cm})$

6 OSB panel $(2.5 \mathrm{~cm})$

Solution 5

*It depends on climate zone

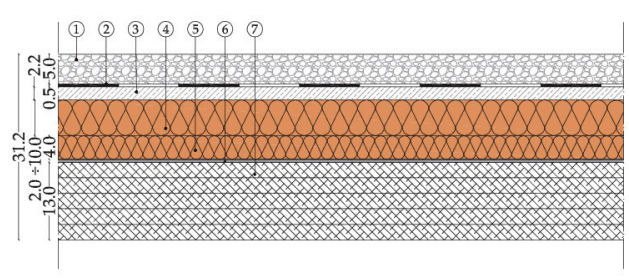

\author{
1 Gravel $(5 \mathrm{~cm})$ \\ 2 Bituminous waterproofing sheet $(0.5 \mathrm{~cm})$ \\ 3 Wood cement panel $(2.2 \mathrm{~cm})$ \\ 4 Wood fiber (high density $-2 \div 10^{*} \mathrm{~cm}$ ) \\ 5 Wood fiber (low density $-4 \mathrm{~cm}$ ) \\ 6 Vapour barrier $(0.45 \mathrm{~cm})$ \\ 7 XLAM panel $(13 \mathrm{~cm})$ \\ *It depends on climate zone
}

Figure 3. Stratigraphy of the roofs for each analyzed solution.

\title{
4. Results and Discussion
}

According to the solutions described in Section 3.1, Table 3 lists thermodynamic properties of the technological solutions assumed for the EW.

As shown in Table 3, the technological solution considered as a reference for the study, characterized by a reinforced concrete frame structure, with the load-bearing element of the EW consisting of lightweight bricks, and external insulation with wood fiber (Table 1, S1), has the largest surface mass mainly due to the density of lightweight bricks $\left(800 \mathrm{~kg} / \mathrm{m}^{3}\right)$. This also guarantees the highest number of hours in terms of time shift $(>20 \mathrm{~h})$. The most 
noticeable and significant difference occurs with solution 2 with respect to all analyzed thermo-dynamic properties. For instance, the $\mathrm{S}_{\mathrm{S}} \mathrm{M}_{\mathrm{s}}$ value is about four times higher than that of S2, or the time shift is more than double. This is particularly important in the summer season when the time shift is essential to avoid the maximum internal temperature during the day.

Table 3. Dynamic thermal characteristics of the analyzed technological solutions: The surface mass $\left(\mathrm{M}_{\mathrm{s}}\right)$, the periodic thermal transmittance $\left(\mathrm{Y}_{\mathrm{IE}}\right)$, the attenuation $\left(\mathrm{f}_{\mathrm{d}}\right)$, and the time shift $(\varphi)$.

\begin{tabular}{ccccc}
\hline Solution & $\mathbf{M}_{\mathbf{s}}$ & $\mathbf{Y}_{\mathbf{I E}}$ & $\mathbf{f}_{\mathbf{d}}$ & $\boldsymbol{\varphi}$ \\
\hline & $\mathbf{( k g / \mathbf { m } ^ { \mathbf { 2 } }}$ & $\mathbf{( W / \mathbf { m } ^ { \mathbf { 2 } } \mathbf { K } )}$ & & (hours) \\
\hline S1 & 329 & 0.003 & 0.015 & 21.11 \\
S2 & 79 & 0.087 & 0.446 & 8.14 \\
S3 & 152 & 0.018 & 0.106 & 15.89 \\
S4 & 118 & 0.05 & 0.226 & 11.88 \\
S5 & 207 & 0.008 & 0.041 & 17.18 \\
\hline
\end{tabular}

For the other technological solutions, although they do not have a surface mass of $230 \mathrm{~kg} / \mathrm{m}^{2}$ [8], they are all characterized by a periodic thermal transmittance lower than $0.1 \mathrm{~W} / \mathrm{m}^{2} \mathrm{~K}$ and a time shift greater than $8 \mathrm{~h}$. Consequently, considering the thermodynamic properties, all solutions comply with the current legislation [8] and they can be used as alternatives to the recurrent solution for the construction of school buildings in Italy (Table 1, S1). The wooden solutions (S4 and S5) show the main differences in terms of the periodic thermal transmittance and attenuation. The solution with the XLAM structure (S5) performs better as it characterized by a lower value for both parameters due to its higher surface mass. The dry solution with a cement board panel (Table 1, S2) has the lowest thermodynamic property values in terms of surface mass and time shift as it is mainly composed of materials characterized by low density and reduced thickness. However, in comparison to the others, it has the advantage of being a dry solution, thereby having shorter installation times and greater flexibility over time.

Figure 4 shows a graph of the hourly variation in the internal surface temperature of the south-facing EW (thermal zone: Class) compared to the external temperature on the designed day for the summer season (15 July).

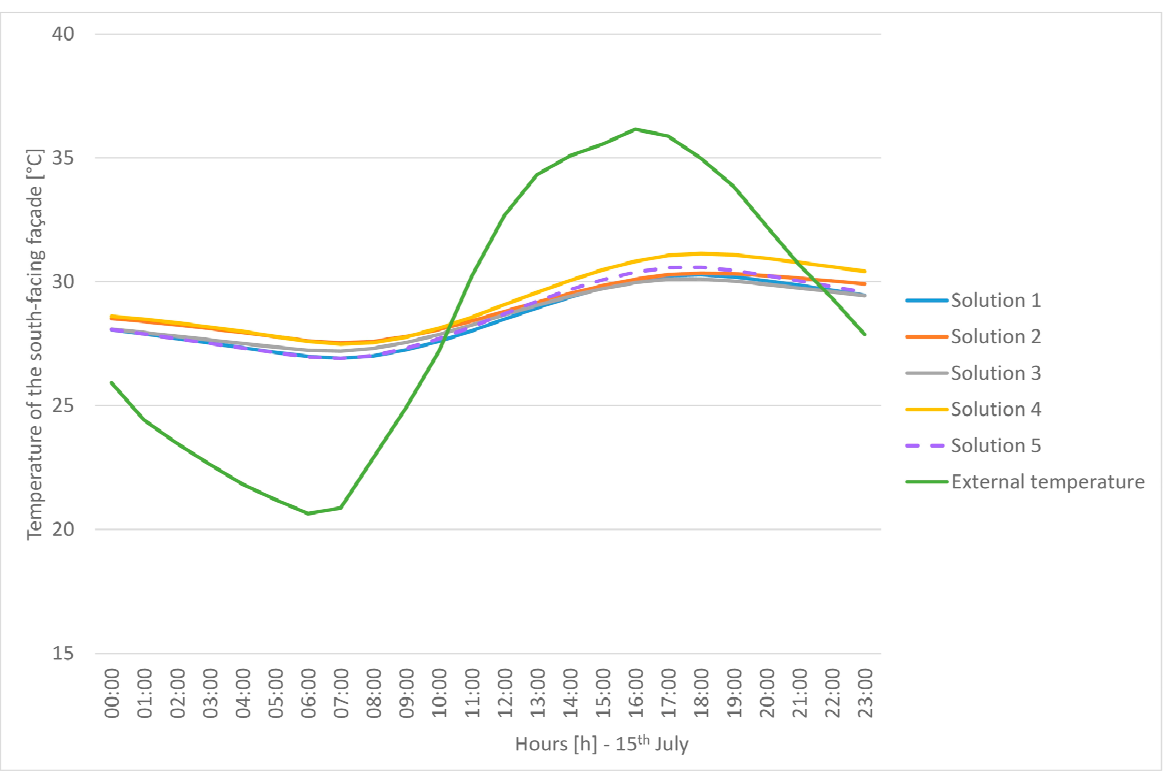

Figure 4. Variation in the internal surface temperature for the southern façade. 
Figure 4 shows that the different technological solutions for the EW, considering the variation in the internal surface temperature, which can negatively affect the internal thermal comfort conditions, are characterized by the same trend, exhibiting a maximum variation of about $3{ }^{\circ} \mathrm{C}$. The solution with platform frame load-bearing structure and double OSB panel with external insulation in wood fiber (Tables 1 and 2, S4) has the highest internal surface temperature at 6:00 p.m. with a maximum peak of $31^{\circ} \mathrm{C}$. The lowest internal surface temperature $\left(27^{\circ} \mathrm{C}\right)$ is attained by S1 and S5 because of the higher surface mass. It is fundamental to control this variation to ensure thermal comfort for the occupants within classrooms during summer season as well.

Figure 5 shows the graph of energy needs for heating and cooling for the reference model considering the different structural and technological solutions (Tables 1 and 2).

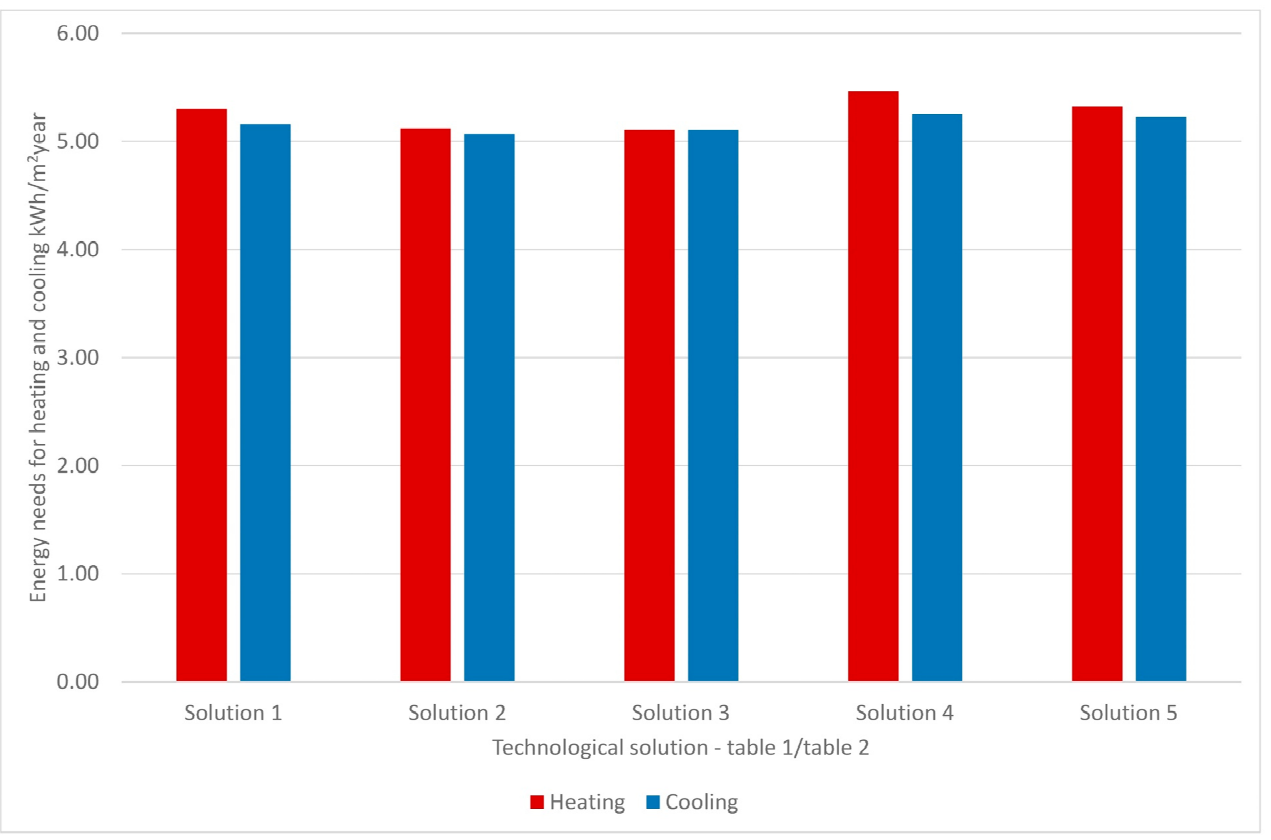

Figure 5. Energy needs for heating and cooling $\left(\mathrm{kWh} /\left(\mathrm{m}^{2} \mathrm{year}\right)\right)$. The final energy needs for heating and cooling was evaluated with an energy simulation with Design Builder considering the setup of the software as explained in Section 3.1 Input data.

Regarding energy demand for heating and cooling, the analyzed technological solutions showed similar behavior, with no significant difference between them (Figure 5). This is mainly because, for an appropriate comparison, all the technological solutions have the same thermal transmittance equal to half of that required by the current energy legislation for the reference building. The energy needs for both heating and cooling are about $5 \mathrm{kWh} /\left(\mathrm{m}^{2}\right.$ year $)$. The solution with platform frame structure, double OSB panel, and external insulation in wood fiber (Table 1, S4) has a slightly higher energy demand.

Figure 6 indicates the annual primary energy demand for the I1 model, located in the city of Florence, considering the different technological solutions analyzed.

Figure 6 reports that the annual primary energy demand of the typological model is about $25 \mathrm{kWh} /\left(\mathrm{m}^{2}\right.$ year) for each proposed technological solution. The graph also shows that artificial lighting and the use of internal equipment (such as computers, interactive whiteboard, printers, etc.) requires less electricity (lower primary energy demand) than all other parameters. This is closely related to the intended use of these buildings. We conclude that the energy performance of the building in terms of annual primary energy demand is the same considering all five solutions. 


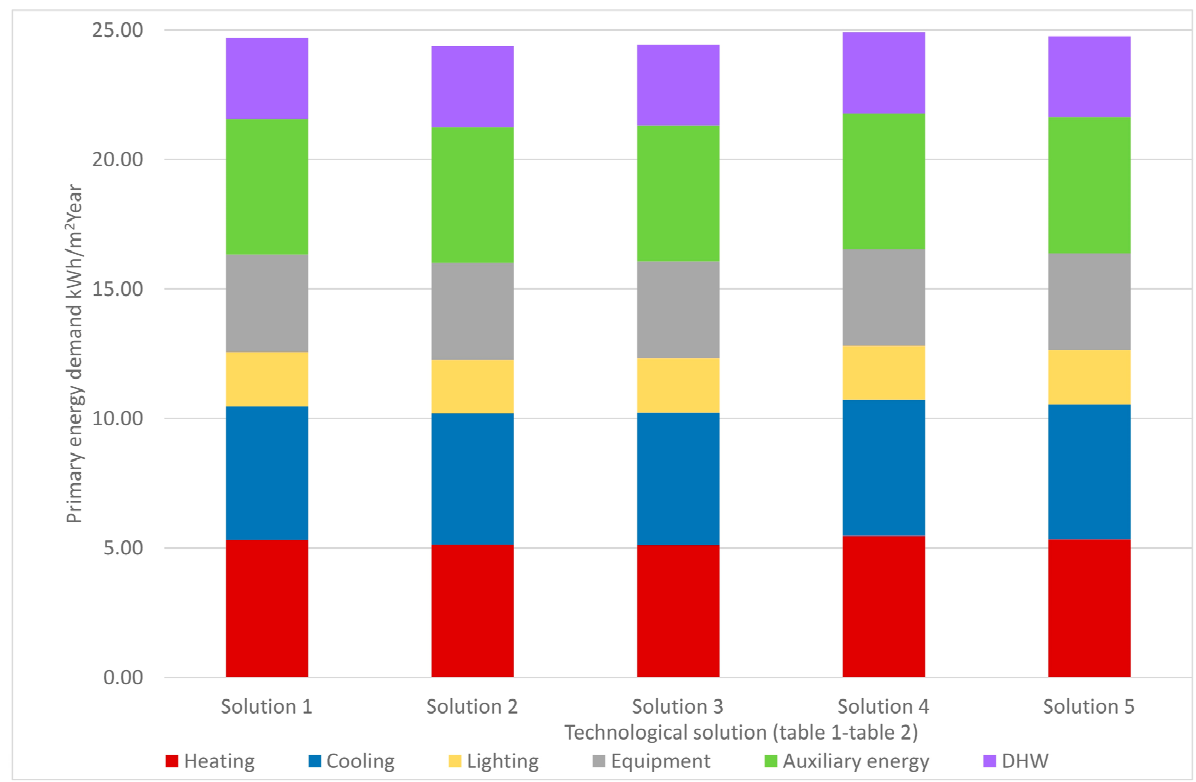

Figure 6. Primary energy demand $\left(\mathrm{kWh} /\left(\mathrm{m}^{2}\right.\right.$ year $\left.)\right)$ for the five technological solutions. DHW, domestic hot water.

The electricity needs of the building are mainly satisfied by a photovoltaic system $\left(0.15 \mathrm{kWp} / \mathrm{m}^{2}\right.$, on grid) installed on the roof in an east/west orientation, tilt angle of $10^{\circ}$, and distance between the rows of photovoltaic panels of $0.70 \mathrm{~m}$. In this configuration, the system produces $120 \mathrm{kWh} /\left(\mathrm{m}^{2}\right.$ year) (calculated with respect to the floor area of the building) with about $300 \mathrm{~m}^{2}$ of photovoltaic panels [74].

Figure 7 shows the $\mathrm{CO}_{2}$ emissions of the typological model taken as reference, located in Florence, considering the emissions due to the construction of the building, the construction of the photovoltaic system on the roof, and the consumption during the operational phase (heating, cooling, artificial lighting, auxiliary energy, equipment, and domestic hot water).

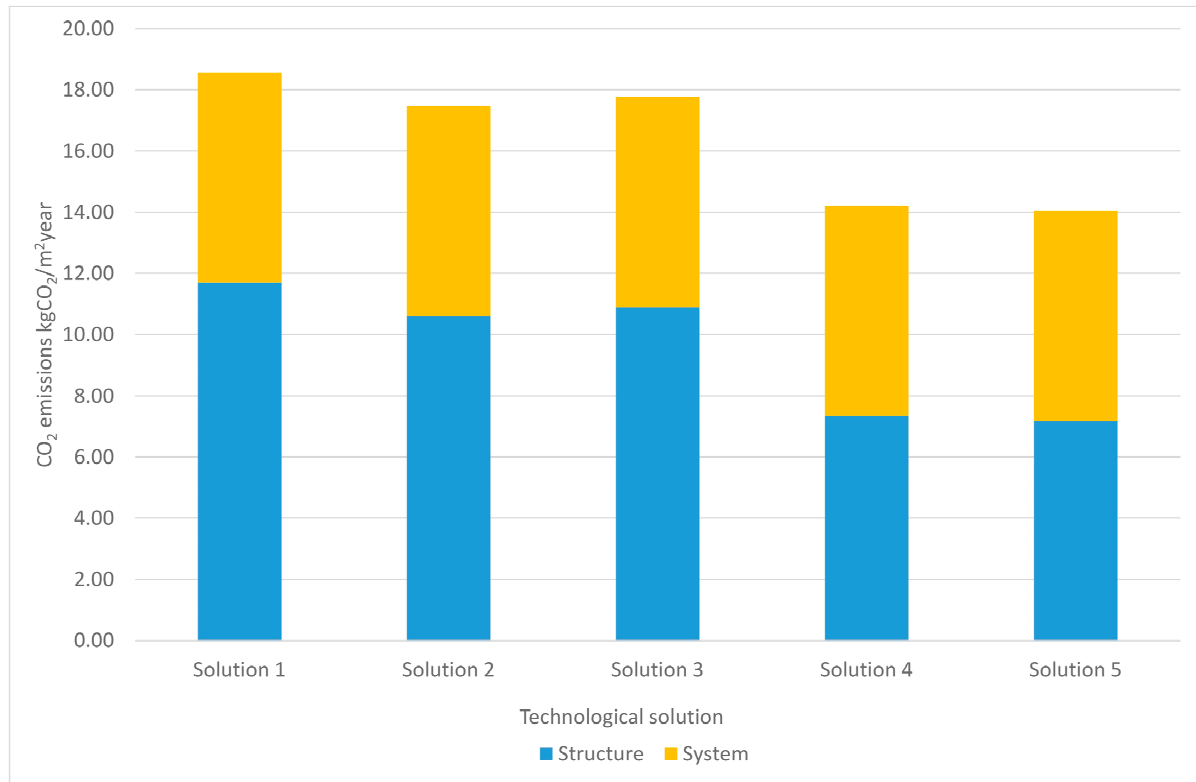

Figure 7. $\mathrm{CO}_{2}$ emissions $\left(\mathrm{kgCO}_{2} /\left(\mathrm{m}^{2}\right.\right.$ year $\left.)\right)$ for the whole building construction for the five technological solutions. Structure represents the $\mathrm{CO}_{2}$ emissions for the building; system represents the $\mathrm{CO}_{2}$ emissions for the photovoltaic system. The value of $\mathrm{CO}_{2}$ emissions refers to the product, end of life, benefits, and load beyond the system boundary and servicing stages. 
Figure 7 shows that the solution with reinforced concrete structure and lightweight bricks with external insulation in wood fiber (Table 1, S1) is characterized by the highest $\mathrm{CO}_{2}$ emissions produced to the atmosphere during the construction phase of the building: About $12 \mathrm{kgCO}_{2} /\left(\mathrm{m}^{2}\right.$ year). Conversely, the solutions with a steel structure have an environmental impact related to the construction phase of about $11 \mathrm{kgCO}_{2} /\left(\mathrm{m}^{2}\right.$ year). The other solutions with a wooden structure (Table 1, S4 and S5) are comparable, emitting about $7 \mathrm{kgCO}_{2} /\left(\mathrm{m}^{2}\right.$ year $)$ into the atmosphere for the same phase.

The emissions due to the construction of the photovoltaic panels installed on the roof to meet the electricity needs of the building are the same for each solution analyzed about $6 \mathrm{kgCO}_{2} /\left(\mathrm{m}^{2}\right.$ year$)$. However, all the solutions are characterized by low emissions because natural materials were chosen, such as the wood fiber for the thermal insulation layer. The use of wooden materials reduces the $\mathrm{CO}_{2}$ emissions and thereby the GWP because of the decrease in the carbon dioxide due to the process of photosynthesis during its life cycle being considered during the calculation.

Figure 7 shows that the $\mathrm{CO}_{2}$ emissions produced into the atmosphere during the building's operational phase are zero as the electricity needs are powered and mainly satisfied by the photovoltaic system installed on the roof. Regarding $\mathrm{CO}_{2}$ emissions, all the technological solutions for the EWs can be used for the construction of carbon-zero kindergartens in Italy, having a GWP of $<20 \mathrm{kgCO}_{2} /\left(\mathrm{m}^{2}\right.$ year) for the construction phase and $0 \mathrm{kgCO}_{2} /\left(\mathrm{m}^{2}\right.$ year $)$ for the operational phase.

Lastly, to determine the best solution in terms of energy, environmental, and economic sustainability, the EW-load-bearing structure binomial was considered since it has strong influences on both the environmental impact and the cost of construction. Considering energy sustainability, we verified that the solutions are comparable and equally adoptable.

Firstly, regarding environmental impact, Figure 8 shows the incidence in percentage, referring to the total for all construction, of the three indices for the environmental evaluation in this phase (GWP, AP, and PENRT) for both the EW and the relative structural solution.

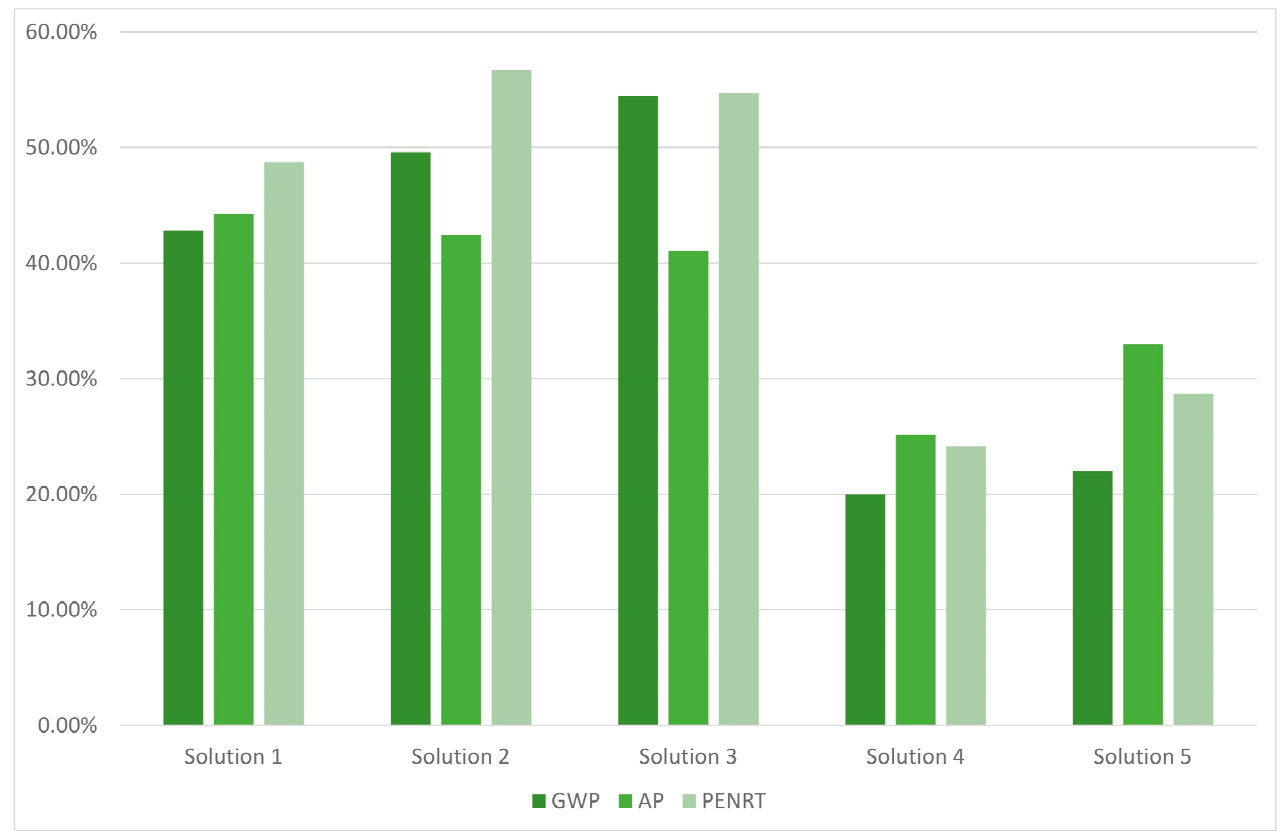

Figure 8. Environmental evaluation through global warming potential (GWP), acidification potential (AP), and total use of non-renewable primary energy resources (PENRT) indexes of the different technological and structural solutions.

Considering the three indices, we found that the wooden structural solutions, one with a platform frame and the other with XLAM (Table 1, S1 and S5), have values considerably lower than the other solutions calculated with respect to the whole construction. with a 
difference of about $20 \%$ compared to the other proposed solutions. This is mainly because the wooden structural solutions have an overall negative value if we consider the product stage (A1-A3), the end-of-life stage (C3-C4), and the benefit and loads beyond the system boundary (D1-D4). For the other analyzed solutions, those adopting a steel structure are characterized by a higher PENRT, mainly due to the incidence of structural elements such as pillars ( $14.5 \%$ of total) and steel main beams ( $18.5 \%$ of total). Solution 3 is characterized by a worse environmental impact value due not only to the steel structure but also to the EW composed of autoclaved aerated concrete blocks that have a GWP of $69.35 \mathrm{kgCO}_{2} / \mathrm{m}^{2}$, an acidification potential of $0.11 \mathrm{kgSO}_{2} / \mathrm{m}^{2}$, and a PENRT of 514.11 MJ referring to the total surface of the external wall. These high values are connected to the absence of a wood fiber insulating layer, which provides an advantage in the overall balance.

Figure 9 shows the results in terms of the normalized indexes (GWP, primary energy demand, and cost) with respect to the reference solution (Table 1, S1) for the different EW-structure combinations. All indexes were evaluated with respect to the area of the reference model (Figure 1). Figure 10 illustrates the overall assessment of the environmental, energy, and economic sustainability (sum of the three normalized aspects) of the different technological solutions for the EW and the related structural solution for the construction of a low-carbon school in Italy or in areas characterized by the same climatic conditions.

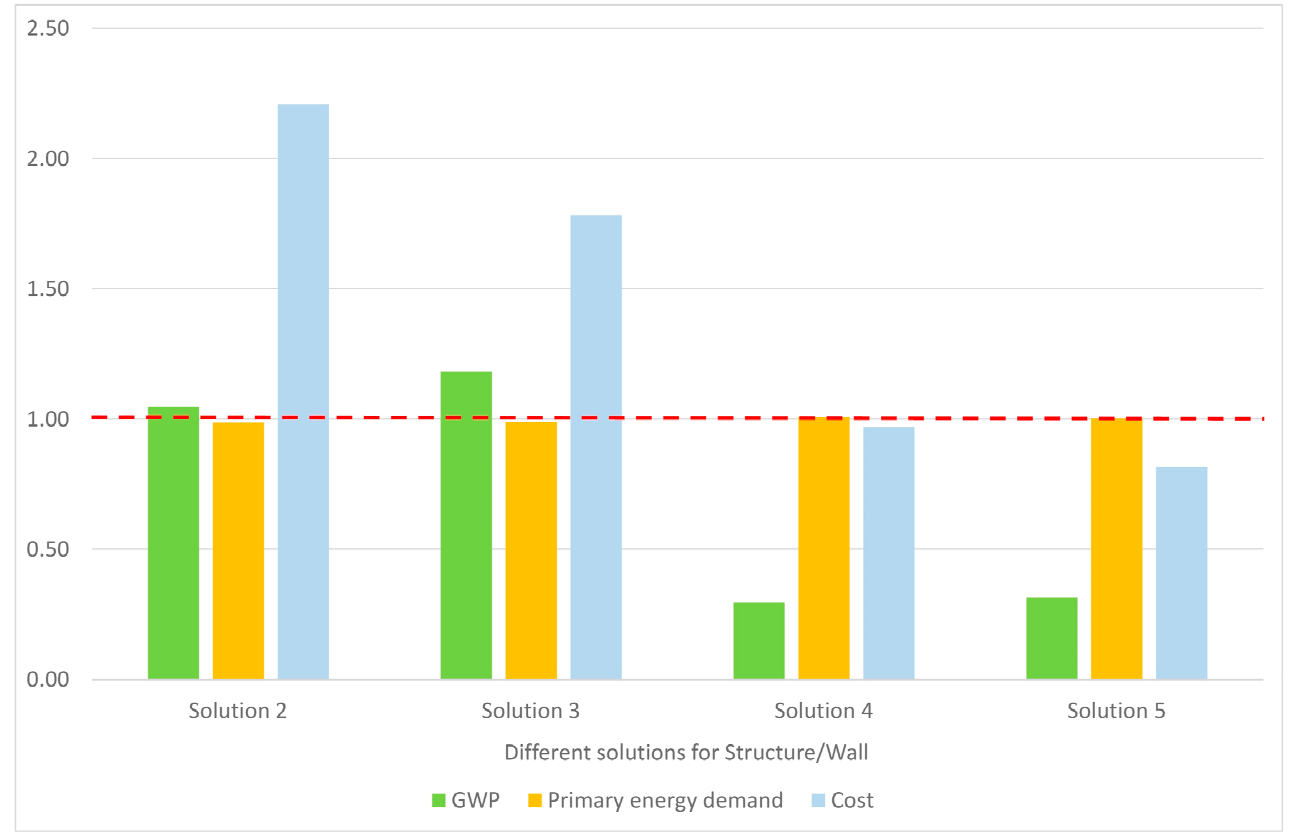

Figure 9. Environmental (GWP), energy (primary energy demand), and economic (cost) evaluation of the different technological and structural solutions. Each index was evaluated separately. The values for GWP and Cost are calculated considering the sum of the single value for each element of both EW and structure for each technological solution. Specifically, the value of GWP is estimated by the sum of the impact of each element of the EW technological solutions and the structure solutions with respect to the GWP of the entire building (impact \%). The value of the Primary energy demand is calculated through energy simulation (Table A2). The values in the graph are normalized with respect to solution 1 (Table 1) with lightweight-brick wall and concrete structure.

Solutions 2 and 4 in Figure 9, which adopt a steel structure combined with a dry EW and aerated autoclaved concrete blocks, respectively, have a higher cost per meter square of area of the building, about 749 and $605 € / \mathrm{m}^{2}$, respectively. Considering the primary energy demand, the result previously shown was confirmed again. Considering the environmental impact in terms of GWP, the same trend was found: The highest value is attained by solution 3 , with an increase of about $20 \%$ with respect to the reference solution. Figure 10 shows that considering the environmental, energy, and economic sustainability 
for the construction of the structure and an EW for a kindergarten, wooden solutions are preferable, providing an initial investment comparable with the reference solution (Table 1, S1) and ensuring the same energy performance with the lowest environmental impact.

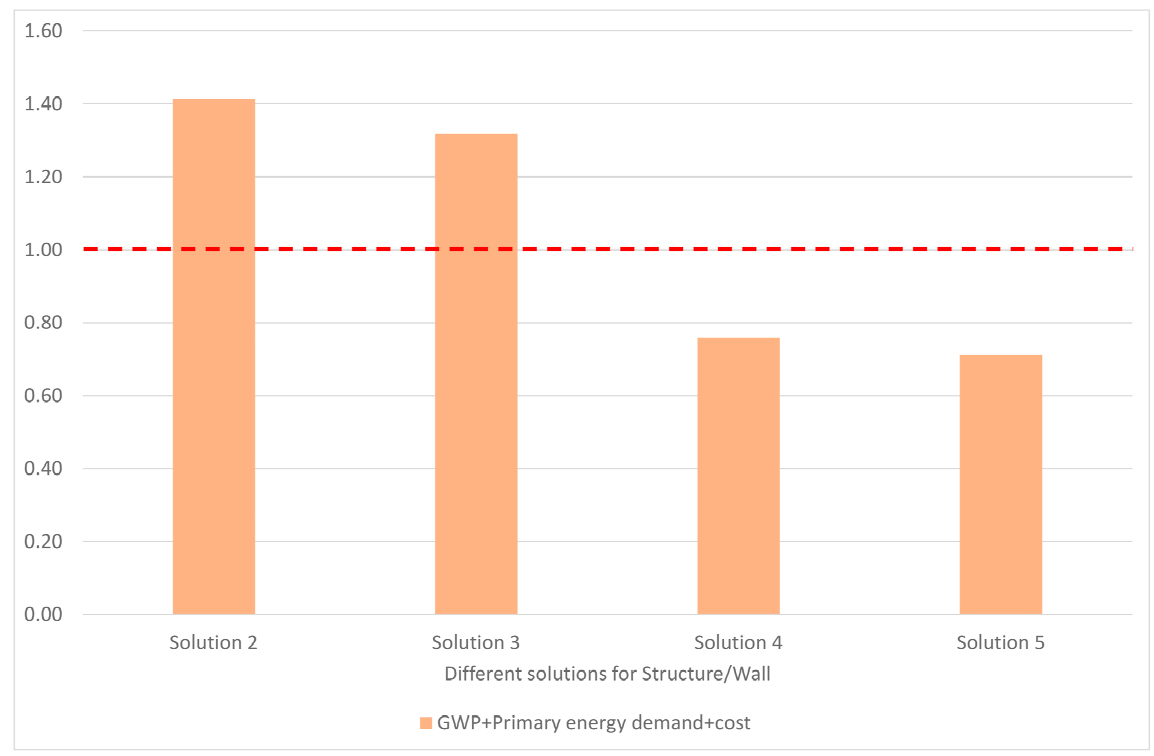

Figure 10. Environmental (GWP), energy (primary energy demand), and economic (cost) sustainability evaluation of the different technological and structural solutions. The values in the graph are normalized with respect to solution 1 (Table 1) with lightweight-brick wall and concrete structure.

\section{Conclusions}

In conclusion, from our analysis on the different types of building envelope, we conclude that all of them can be used for the construction of zero-emissions kindergartens in Italy.

All the proposed technological solutions for the external wall satisfy the requirements of current energy legislation in terms of surface mass and/or periodic thermal transmittance. In addition, a time shift greater than eight hours is ensured by all the analyzed solutions. From an energy performance point of view, the technological solutions behave similarly in terms of the annual primary energy demand of the building; among them, the difference is lower than $1 \%$. All solutions have a low annual primary energy demand of about $25 \mathrm{kWh} /\left(\mathrm{m}^{2}\right.$ year $)$.

All the solutions proposed for the building envelope emit less than $20 \mathrm{kgCO}_{2} /\left(\mathrm{m}^{2}\right.$ year $)$ into the atmosphere However, solutions 1, 2, and 3 have a higher environmental impact considering the $\mathrm{CO}_{2}$ emissions during the construction phase. During the operational phase, the emissions are zero as the electricity is produced through renewables.

In the construction of a school building, it is necessary to consider the total cost of construction, corresponding to the total initial investment, because it plays an important role. Thus, two elements (EW and structure) that considerably affect cost were deeply analyzed and discussed considering their environmental impact, energy performance, and cost. The wooden solutions (Table 1, S1 and S5) are the most sustainable, as they provide the best compromise between these three fundamental aspects for the construction of a low-carbon school in the Mediterranean area.

Currently, schools are representative buildings both on social and cultural levels; at it is also important to ensure an education to all children in a healthy and environmentalfriendly place, supporting their environmental education. To configure solutions that are sustainable both from energy-environmental and economic viewpoints, designers must integrate and address the aspects with an interdisciplinary approach from the earliest stages of the design process of a school building. 
We proposed a method here to define the building envelope and the load-bearing structure by correlating the energy, environmental, and economic aspects. So, this considering at the same time an index for the evaluation of the environmental impact (GWP), the cost of the solution with respect to the price list of the considered location and finally an energy rating to evaluate the performance of the building during service life with the use of the proposed solutions (for instance primary energy demand). What has been applied here to the city of Florence can be used in any social and climatic context (for instance North Europe) firstly by checking the more suitable technological solutions for the considered climate, updating the minimum requirements for the thermal properties according to the current legislation in chosen site and finally updating the climate characteristics for the energy simulation. Moreover, by performing an economic evaluation of different technological solutions according to the construction price list of the considered locations. This could be done to evaluate the sustainability of a school building in a preliminary stage of the design process and the proposed methodology could be considered as a strategic result for this reason. The application in Florence is only a way to show in a better and concise way the results and the related discussion. One of the future developments of the research could be applying the same method to different building type located in different climate conditions, obviously taking into account the most proper technological solutions or structural solutions for the considered intended use.

Author Contributions: Conceptualization, F.B., V.D.N. and C.C.; methodology, F.B., V.D.N. and C.C.; software, C.C.; validation, C.C. and V.D.N.; formal analysis, C.C. and V.D.N.; data curation, C.C. and V.D.N.; writing-original draft preparation, C.C.; writing-review and editing, C.C., V.D.N. and F.B.; visualization, C.C. and V.D.N.; supervision, F.B.; project administration F.B. and V.D.N. All authors have read and agreed to the published version of the manuscript.

Funding: This research received no external funding.

Conflicts of Interest: The authors declare no conflict of interest.

\section{Appendix A}

Table A1. GWP, cost and primary energy value for the calculation of the normalized values.

\begin{tabular}{|c|c|c|c|}
\hline Solution & GWP $^{1,2}$ & Cost $^{2}$ & Primary Energy Demand \\
\hline & (Impact \%) & $\left(€ / \mathrm{m}^{2}\right)$ & (kWh/m²year) \\
\hline S1 & 5.015 & 339.72 & 24.70 \\
\hline S2 & 5.933 & 749.56 & 24.38 \\
\hline S3 & 5.257 & 605.67 & 24.44 \\
\hline S4 & 1.483 & 329.16 & 24.91 \\
\hline S5 & 1.5784 & 277.50 & 24.75 \\
\hline
\end{tabular}

${ }^{1}$ The GWP is estimate by the sum of the impact of each element (for instance insulation layer, pillar, frame, slab, etc.) of the external wall technological solutions and the structure solutions with respect to the GWP of the entire building (impact \%). ${ }^{2}$ The values are the sum of the single value for each element of both EW and structure.

Table A2. Normalized values of each parameters with respect to the solution 1 (S1).

\begin{tabular}{ccccc}
\hline Solution & GWP & Cost & Primary Energy Demand & Sum $^{\mathbf{1}}$ \\
\hline S1 & Reference & Reference & Reference solution & 1 \\
S2 & solution & solution & 0.99 & 1.41 \\
S3 & 1.18 & 2.21 & 0.99 & 1.32 \\
S4 & 1.05 & 1.78 & 1.01 & 0.76 \\
S5 & 0.29 & 0.97 & 1.01 & 0.71 \\
\hline
\end{tabular}

${ }^{1}$ To obtain this value the sum of GWP, Cost and Primary energy demand normalized values is evaluated with respect 1 that represent the solution S1 (reference solution for the normalization). 


\section{References}

1. Pietrapertosa, F.; Tancredi, M.; Salvia, M.; Proto, M.; Pepe, A.; Giordano, M.; Afflitto, N.; Sarricchio, G.; Di Leo, S.; Cosmi, C. An educational awareness program to reduce energy consumption in schools. J. Clean. Prod. 2021, 278, 123949. [CrossRef]

2. Tasc1, B.G. "Sustainability" Education by Sustainable School Design. Procedia Soc. Behav. Sci. 2015, 186, 868-873. [CrossRef]

3. Tucker, R.; Izadpanahi, P. Live green, think green: Sustainable school architecture and children's environmental attitudes and behaviors. J. Environ. Psychol. 2017, 51, 209-216. [CrossRef]

4. European Council. Presidency Conclusions. Barcelona European Council 15 and 16 March 2002 (SN 100/1/02 REV 1). Barce-lona. 2002. Available online: https:/ /www.consilium.europa.eu/uedocs/cms_data/docs/pressdata/en/ec/71025.pdf (accessed on 27 January 2021).

5. European Commission. Barcelona Objectives. The Development of Childcare Facilities for Young Children in Europe with a View to Sustainable and Inlusive Growth. Available online: https:/ / ec.europa.eu/info/sites/info/files/130531_barcelona_en_0.pdf (accessed on 27 January 2021).

6. Istat (Istituto Nazionale di Statica). Offerta Asili Nido e Servizi Integrativi per la Prima Infanzia anno Educativo 2018/2019. Italy. 2020. Available online: https:/ / www.istat.it/it/files / /2020/10/REPORT_ASILI-NIDO-2018-19.pdf (accessed on 27 January 2021).

7. Ecosistema Scuola. In XIX Rapporto di Legambiente Sulla Qualità Dell'edilizia Scolastica, delle Strutture e dei Servizi; Legambiente: Roma, Italy, 2018.

8. Governo Italiano. Decreto Ministeriale del 26 Giugno 2015. Applicazione delle Metodologie di Calcolo delle Prestazioni Energetiche e Definizione delle Prescrizioni e dei Requisiti Minimi Degli Edifice; Ministero dello Sviluppo Economico: Roma, Italy, 2015.

9. Edilizia Scolastica e Sicurezza Nelle Scuole; Camera Dei Deputati: Roma, Italy, 2020; Available online: https://www.camera.it/ temiap/documentazione/temi/pdf/1105567.pdf (accessed on 29 January 2021).

10. Ministero dell'Istruzione. Scuole Sicure. Available online: https://www.istruzione.it/edilizia_scolastica/fin-scuole-sic.shtml (accessed on 29 January 2021).

11. Ministero dell'Istruzione. Scuole Belle. Available online: https://www.istruzione.it/edilizia_scolastica/fin-scuole-belle.shtml (accessed on 29 January 2021).

12. Ministero dell'Istruzione. Scuole Antisismiche. Available online: https://www.istruzione.it/edilizia_scolastica/fin-scuoleantisism.shtml (accessed on 29 January 2021).

13. Ministero dell'Istruzione. Poli per L'infanzia. Available online: https://www.istruzione.it/edilizia_scolastica/fin-poli-infanzia. shtml (accessed on 29 January 2021).

14. European Commission. 2030 Climate \& Energy Framework. 2020. Available online: https://ec.europa.eu/clima/policies/ strategies/2030_en (accessed on 16 December 2020).

15. Decreto Ministeriale del 18 Dicembre 1975. Norme Tecniche Aggiornate Relative alla Edilizia Scolastica, ivi Compresi gli Indici Minimi di Funzionalità Didattica, Edilizia ed Urbanistica, da Osservarsi nella Esecuzione di Opere di Edilizia Scolastica; Governo Italiano: Rome, Italy, 1975.

16. Tian, Z.; Zhang, X.; Jin, X.; Zhou, X.; Si, B.; Shi, X. Towards adoption of building energy simulation and optimization for passive building design: A survey and a review. Energy Build. 2018, 158, 1306-1316. [CrossRef]

17. Harkouss, F.; Fardoun, F.; Biwole, P.H. Passive design optimization of low energy buildings in different climates. Energy 2018, 165, 591-613. [CrossRef]

18. Bazzocchi, F.; Ciacci, C.; Di Naso, V. Linee guida per la realizzazione di scuole dell'infanzia carbon zero in Italia. In New Horizons for Sustainable Architecture, Proceedings of New Horizon for Sustainable Architecture, Catania, Italy, 10 December 2020; online ed.; Cascone, S.M., Margani, G., Speranza, V., Eds.; EdicomEdizioni: Italy, Gorizia, 2020; pp. 932-949. ISBN 978-88-96386-94-1.

19. Marrone, P.; Gori, P.; Asdrubali, F.; Evangelisti, L.; Calcagnini, L.; Grazieschi, G. Energy Benchmarking in Educational Buildings through Cluster Analysis of Energy Retrofitting. Energies 2018, 11, 649. [CrossRef]

20. Dall' $\mathrm{O}^{\prime}$, G.; Sarto, L. Potential and limits to improve energy efficiency in space heating in existing school buildings in northern Italy. Energy Build. 2013, 67, 298-308. [CrossRef]

21. Zinzi, M.; Battistini, G.; Ragazzini, V. Energy and Environmental Monitoring of a School Building Deep Energy Renovation in Italy. Energy Procedia 2015, 78, 3318-3323. [CrossRef]

22. Stocker, E.; Tschurtschenthaler, M.; Schrott, L. Cost-optimal renovation and energy performance: Evidence from existing school buildings in the Alps. Energy Build. 2015, 100, 20-26. [CrossRef]

23. De Santoli, L.; Fraticelli, F.; Fornari, F.; Calice, C. Energy performance assessment and a retrofit strategies in public school buildings in Rome. Energy Build. 2014, 68, 196-202. [CrossRef]

24. Ascione, F.; Bianco, N.; Mauro, G.M.; Napolitano, D.F. Building envelope design: Multi-objective optimization to minimize energy consumption, global cost and thermal discomfort. Application to different Italian climatic zones. Energy 2019, 174, 359-374. [CrossRef]

25. Agenzia Nazionale per le Nuove Tecnologie, L'energia e lo sviLuppo Economico. Rapporto Annuale. Efficienza Energetica. Analisi e Risultati Delle Policy di Efficienza Energetica nel Nostro Paese; Agenzia Nazionale: Roma, Italy, 2020.

26. Agenzia Nazionale per le Nuove Tecnologie, L'energia e lo Sviluppo Economico. Guida al Contenimento della Spesa Energetica nelle Scuole; Agenzia Nazionale: Roma, Italy, 2012. 
27. Pereira, L.D.; Raimondo, D.; Corgnati, S.P.; Da Silva, M.G. Energy consumption in schools-A review paper. Renew. Sustain. Energy Rev. 2014, 40, 911-922. [CrossRef]

28. Bianchi, F.; Altomonte, M.; Cannata, M.E.; Fasano, G. Report RSE/2009/119. Definizione Degli Indici e Livelli di Fabbisogno dei Vari Centri di Consumo Energetico Degli Edifici Adibiti a Scuole-Consumi Energetici Delle Scuole Primarie e Secondarie; Agenzia Nazionale: Roma, Italy, 2009; Available online: https://www.enea.it/it/Ricerca_sviluppo/documenti/ricerca-di-sistemaelettrico/governance/rse119.pdf (accessed on 16 December 2020).

29. Lizana, J.; Serrano-Jiménez, A.; Ortíz, C.; Becerra, J.A.; Friedrich, D. Energy assessment method towards low-carbon energy schools. Energy 2018, 159, 310-326. [CrossRef]

30. Gamarra, A.R.; Istrate, I.; Herrera, I.; Lago, C.; Lizana, J.; Lechón, Y. Energy and water consumption and carbon footprint of school buildings in hot climate conditions. Results from life cycle assessment. J. Clean. Prod. 2018, 195, 1326-1337. [CrossRef]

31. Zanni, D.; Righi, A.; Mora, T.D.; Peron, F.; Romagnoni, P. The Energy Improvement of School Buildings: Analysis and Proposals for Action. Energy Procedia 2015, 82, 526-532. [CrossRef]

32. Kheiri, F. A review on optimization methods applied in energy-efficient building geometry and envelope design. Renew. Sustain. Energy Rev. 2018, 92, 897-920. [CrossRef]

33. Okba, E.M. Building envelope design as a passive cooling technique. In Proceedings of the International Conference Passive Low Energy Cool Built Environment, Santorini, Greece, 19-21 May 2005; pp. 467-473. Available online: http://www.conferences.gr/ fileadmin/shop/pdf/PALENC2005_Volume1.pdf (accessed on 25 November 2020).

34. Criteri Ambientali Minimi per L'affidamento dei Servizi di Progettazione e Lavori per la Nuova Costruzione, Ristrutturazione e Manutenzione di Edifici Pubblici. In Gazzetta Ufficiale della Repubblica Italiana Serie Generale n. 259; Governo Italiano: Roma, Italy, 2017.

35. Shi, X.; Tian, Z.; Chen, W.; Si, B.; Jin, X. A review on building energy efficient design optimization from the perspective of architects. Renew. Sustain. Energy Rev. 2016, 65, 872-884. [CrossRef]

36. Alshamrani, O.S.; Galal, K.; Alkass, S. Integrated LCA-LEED sustainability assessment model for structure and envelope systems of school buildings. Build. Environ. 2014, 80, 61-70. [CrossRef]

37. Saafi, K.; Daouas, N. A life-cycle cost analysis for an optimum combination of cool coating and thermal insulation of residential building roofs in Tunisia. Energy 2018, 152, 925-938. [CrossRef]

38. Alshamrani, O.S.; Alshibani, A. Automated decision support system for selecting the envelope and structural systems for educational facilities. Build. Environ. 2020, 181, 106993. [CrossRef]

39. Llantoy, N.; Chàfer, M.; Cabeza, L.F. A comparative life cycle assessment (LCA) of different insulation materials for buildings in the continental Mediterranean climate. Energy Build. 2020, 225, 110323. [CrossRef]

40. Stazi, F.; Tomassoni, E.; Di Perna, C. Super-insulated wooden envelopes in Mediterranean climate: Summer overheating, thermal comfort optimization, environmental impact on an Italian case study. Energy Build. 2017, 138, 716-732. [CrossRef]

41. Carretero-Ayuso, M.J.; García-Sanz-Calcedo, J. Analytical study on design deficiencies in the envelope projects of healthcare buildings in spain. Sustain. Cities Soc. 2018, 42, 139-147. [CrossRef]

42. Ferrara, M.; Sirombo, E.; Monti, A.; Fabrizio, E.; Filippi, M. Influence of Envelope Design in the Optimization of the Operational Energy Costs of a Multi-family Building. Energy Procedia 2016, 101, 216-223. [CrossRef]

43. Ascione, F.; De Masi, R.F.; De Rossi, F.; Ruggiero, S.; Vanoli, G.P. Optimization of building envelope design for nZEBs in Mediterranean climate: Performance analysis of residential case study. Appl. Energy 2016, 183, 938-957. [CrossRef]

44. Ciacci, C.; Bazzocchi, F.; Di Naso, V. External Wall Technological Solutions for Carbon Zero Schools in Italy. In InnovationsSustainability-Modernity-Openness Energy; Krawczyk, D.A., Skoczo, I., Szatylowicz, E., Eds.; Printing House of Bialystok University of Technology: Byalistock, Poland, 2007; Volume 40, pp. 45-64. [CrossRef]

45. Rad, E.A.; Fallahi, E. Optimizing the insulation thickness of external wall by a novel 3E (energy, environmental, economic) method. Constr. Build. Mater. 2019, 205, 196-212. [CrossRef]

46. D'Agostino, D.; Rossi, F.D.; Marigliano, M.; Marino, C.; Minichiello, F. Evaluation of the optimal thermal insulation thickness for an office building in different climates by means of the basic and modified "cost-optimal" methodology. J. Build. Eng. 2019, 24, 100743. [CrossRef]

47. Vincelas, F.F.C.; Ghislain, T. The determination of the most economical combination between external wall and the optimum insulation material in Cameroonian's buildings. J. Build. Eng. 2017, 9, 155-163. [CrossRef]

48. Zhang, L.; Liu, Z.; Hou, C.; Hou, J.; Wei, D.; Hou, Y. Optimization analysis of thermal insulation layer attributes of building envelope exterior wall based on DeST and life cycle economic evaluation. Case Stud. Therm. Eng. 2019, 14, 100410. [CrossRef]

49. Alsayed, M.F.; Tayeh, R.A. Life cycle cost analysis for determining optimal insulation thickness in Palestinian buildings. J. Build. Eng. 2019, 22, 101-112. [CrossRef]

50. Rosti, B.; Omidvar, A.; Monghasemi, N. Optimal insulation thickness of common classic and modern exterior walls in different climate zones of Iran. J. Build. Eng. 2020, 27, 100954. [CrossRef]

51. Daouas, N.; Hassen, Z.; Ben Aissia, H. Analytical periodic solution for the study of thermal performance and optimum insulation thickness of building walls in Tunisia. Appl. Therm. Eng. 2010, 30, 319-326. [CrossRef]

52. Ciacci, C. Progettazione di scuole NZEB: Nuovi modelli tipologici per la scuola dell'infanzia e la scuola primaria in Italia. In Edilizia Circolare, Proceedings of the Colloquiate 2018; Cagliari, Italy, 14-16 September 2018, Cuboni, F., Desogus, G., Quaquero, E., Eds.; EdicomEdizioni: Gorizia, Italy, 2020; pp. 932-949. ISBN 9788896386750. 
53. US Department of Energy. EnergyPlus Simulation Software. Available online: https://energyplus.net/ (accessed on 4 November 2019).

54. Design Builder v4.5. Available online: https:/ / www.designbuilderitalia.it/ (accessed on 4 November 2019).

55. Regolamento Recante Norme per la Progettazione, L'installazione, L'esercizio e la Manutenzione degli Impianti Termici degli Edifici ai fini del Contenimento dei Consumi di Energia, in Attuazione Dell'art. 4, Comma 4, della L. 9 Gennaio 1991, n. 10 (2) (3); Governo Italiano: Roma, Italy, 1993.

56. Federal Institute for Research on Building, Urban Affairs and Spatial Department, eLCA v0.9.7. Available online: https: //www.bauteileditor.de/ (accessed on 4 November 2019).

57. Leskovar, V.Ž.; Žigart, M.; Premrov, M.; Lukman, R.K. Comparative assessment of shape related cross-laminated timber building typologies focusing on environmental performance. J. Clean. Prod. 2019, 216, 482-494. [CrossRef]

58. Bertagni, S. Sistemi Costruttivi Criteri per la Verifica e la Certificazione della Sostenibilità, 1st ed.; EdicomEdizioni: Monfalcone (Gorizia), Italy, 2016; pp. 82-83.

59. Ylmén, P.; Peñaloza, D.; Mjörnell, K. Life Cycle Assessment of an Office Building Based on Site-Specific Data. Energies 2019, 12, 2588. [CrossRef]

60. Blengini, G.A. Life cycle of buildings, demolition and recycling potential: A case study in Turin, Italy. Build. Environ. 2009, 44, 319-330. [CrossRef]

61. Khan, J.; Arsalan, M.H. Solar power technologies for sustainable electricity generation-A review. Renew. Sustain. Energy Rev. 2016, 55, 414-425. [CrossRef]

62. Estokova, A.; Vilcekova, S.; Porhincak, M. Analyzing Embodied Energy, Global Warming and Acidification Potentials of Materials in Residential Buildings. Procedia Eng. 2017, 180, 1675-1683. [CrossRef]

63. Hollberg, A.; Kiss, B.; Röck, M.; Soust-Verdaguer, B.; Wiberg, A.H.; Lasvaux, S.; Galimshina, A.; Habert, G. Review of visualising LCA results in the design process of buildings. Build. Environ. 2021, 190, 107530. [CrossRef]

64. Bassi, A. Costi per Tipologie Edilizie; Maggioli Editore: Santarcangelo di Romagna, Italy, 2014; pp. 184-185. ISBN 8891605913.

65. Municipality of Ariano Irpino (Avellino). Concorso Internazionale di Progettazione per la Realizzazione del polo Scolastico di Eccellenza Alberghiero ed Agroalimentare. Winner Project: Stima dei Costi Dell'intervento e Quadro Economico Complessivo. Available online: http:/ / www.arianoirpinoattraversolascuola.concorrimi.it/ (accessed on 25 November 2020).

66. Norme Tecniche-Quadro, Contenenti gli Indici Minimi e Massimi di Funzionalità Urbanistica, Edilizia, anche con Riferimento alle Tecnologie in Materia di Efficienza e Risparmio Energetico e Produzione da fonti Energetiche Rinnovabili, e Didattica Indispensabili a Garantire Indirizzi Progettuali di Riferimento Adeguati e Omogenei sul Territorio Nazionale; Governo Italiano: Roma, Italy, 2013.

67. Decreto del Presidente della Repubblica del 5 Dicembre 1997. Determinazione dei Requisiti Acustici Passivi Degli Edifice; Governo Italiano: Roma, Italy, 1997.

68. Approvazione di Norme Tecniche di Prevenzione Incendi, ai Sensi Dell'articolo 15 del Decreto Legislativo 8 Marzo 2006, n. 139 (Codice di Prevenzione Incendi); Ministero dell'Interno: Roma, Italy, 2020.

69. Decreto Ministeriale del 12 Maggio 2016. Prescrizioni per L'attuazione, con Scadenze Differenziate, delle Vigenti Normative in Materia di Prevenzione Degli Incendi per L'edilizia Scolastica; Governo Italiano: Roma, Italy, 2016.

70. Ciacci, C.; Bazzocchi, F.; Di Naso, V.; Rocchetti, A. Influence Of Window To Wall Ratio On Global Energy Consumption Of Nzeb Kindergartens In Italy. In Proceedings of the 16th IBPSA International Conference and Exhibition, Building Simulation 2019, Roma, Italy, 2-4 September 2019; pp. 3063-3070.

71. Bazzocchi, F.; Ciacci, C.; Di Naso, V. Study on solar shading systems for designing nZEB kindergartens in Italy. Riv. Tema 2020, 6, 74-85. [CrossRef]

72. UNI 10339. Impianti Aeraulici a Fini di Benessere. Generalità, Classificazione e Requisiti. Regole per la Richiesta D'offerta, L'offerta, L'ordine e la Fornitura; Ente Nazionale di Normazione: Roma, Italy, 2015.

73. UNI/TS 11330-1 Prestazioni Energetiche Degli Edifici. Parte 1-Determinazione del Fabbisogno di Energia Termica Dell'edificio per la Climatizzazione Estiva ed Invernale; Ente Nazionale di Normazione: Roma, Italy, 2014.

74. Ciacci, C.; Bazzocchi, F.; Di Naso, V.; Rocchetti, A. NZEB schools in Italy: Definition and optimization of system using photovoltaic technology. In Proceedings of the REHABEND 2020-Construction Pathology, Rehabilitation Technology and Heritage Management, Granada, Spain, 28 September-1 October 2020; pp. 1705-1713. 